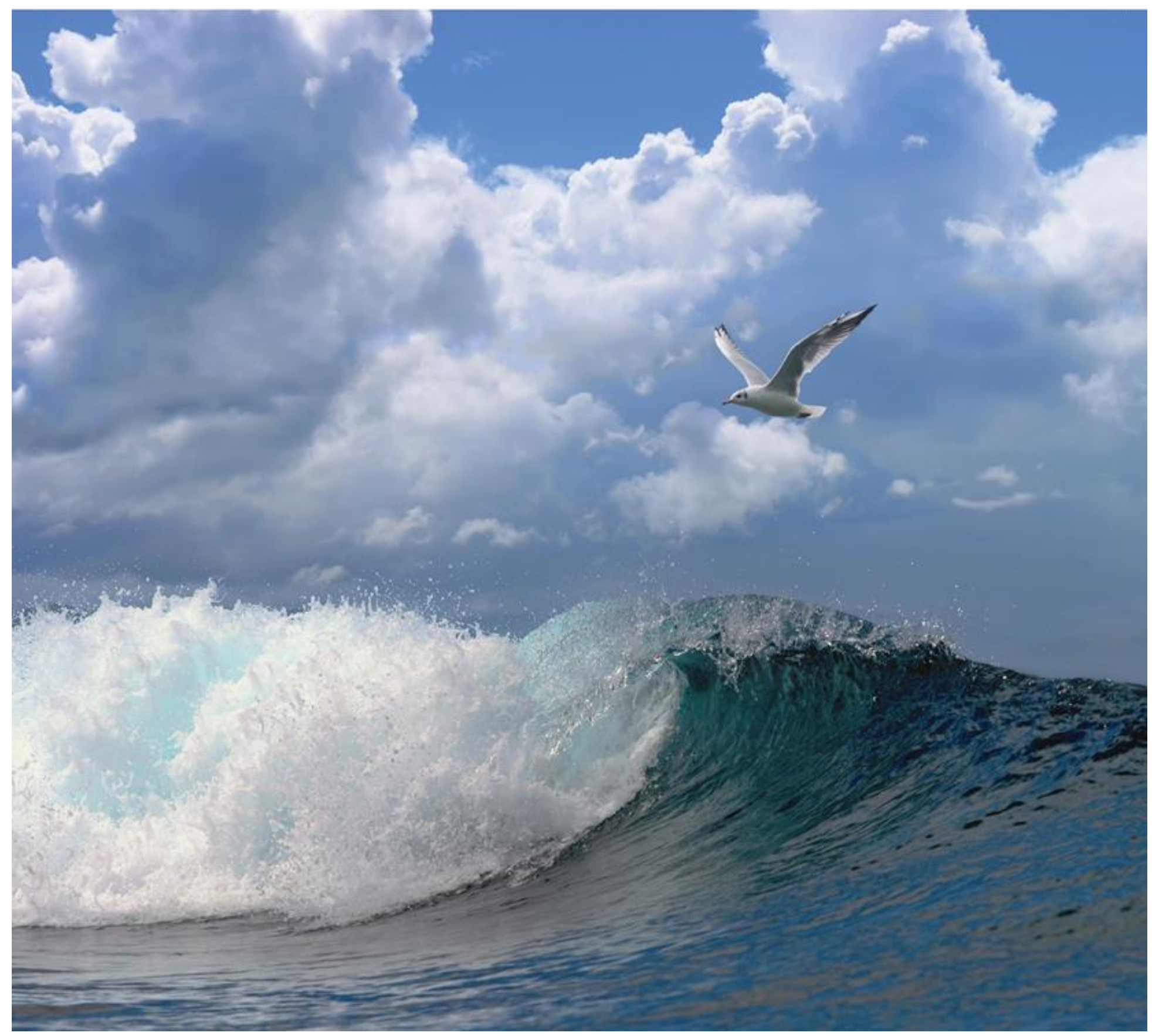

\title{
Pilot studie akoestische telemetrie nabij sluiscomplex IJmuiden
}




\section{Pilot studie akoestische telemetrie nabij sluiscomplex IJ muiden}

Auteur(s): $\quad$ A.B. Griffioen, O.A. van Keeken en H.V. Winter

Publicatiedatum: 30 augustus 2017

Wageningen Marine Research, IJ muiden augustus 2017

Wageningen Marine Research rapport C060/17 
Ben Griffioen, Olvin van Keeken en Erwin Winter, 2017 Pilot studie akoestische telemetrie nabij sluiscomplex IJ muiden. Wageningen Marine Research Wageningen UR (University \& Research centre), Wageningen Marine Research rapport C060/17, 43 blz.

Opdrachtgever: Rijkswaterstaat

T.a.v.: Marco van Wieringen

Postbus 3119 | 2001 DC Haarlem

Dit rapport is gratis te downloaden van https://doi.org/10.18174/421903

Wageningen Marine Research verstrekt geen gedrukte exemplaren van rapporten.

Wageningen Marine Research Wageningen UR is ISO 9001:2008 gecertificeerd.

(c) 2016 Wageningen Marine Research Wageningen UR

Wageningen Marine Research, onderdeel van Stichting Wageningen Research KvK nr. 09098104,

IMARES BTW nr. NL 8113.83.696.B16

Code BIC/SWIFT address: RABONL2U IBAN code: NL 73 RABO 0373599285
De Directie van Wageningen Marine Research is niet aansprakelijk voor gevolgschade, noch voor schade welke voortvloeit uit toepassingen van de resultaten van werkzaamheden of andere gegevens verkregen van Wageningen Marine Research opdrachtgever vrijwaart Wageningen Marine Research van aanspraken van derden in verband met deze toepassing.

Dit rapport is vervaardigd op verzoek van de opdrachtgever hierboven aangegeven en is zijn eigendom. Niets uit dit rapport mag weergegeven en/of gepubliceerd worden, gefotokopieerd of op enige andere manier gebruikt worden zonder schriftelijke toestemming van de opdrachtgever. 


\section{Inhoud}

$\begin{array}{lr}\text { Samenvatting } & 4\end{array}$

$1 \quad$ Inleiding $\quad 5$

2 Kennisvraag en doel $\quad 6$

$\begin{array}{llr}3 & \text { Methode } & 7\end{array}$

$\begin{array}{lll}3.1 & \text { Opstelling ontvangers en zenders } & 7\end{array}$

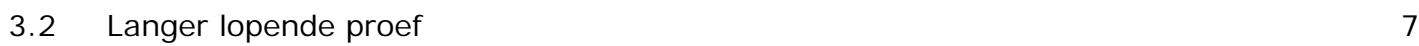

$\begin{array}{lll}3.3 & \text { Kort lopende proef } & 11\end{array}$

$\begin{array}{lll}3.4 & \text { Techniek } & 12\end{array}$

3.4.1 Werking VEMCO techniek 12

4 Resultaten $r$

$\begin{array}{lll}4.1 & \text { Lang lopende proef Middensluis } & 14\end{array}$

$\begin{array}{lll}4.1 .1 & \text { Zender A } & 14\end{array}$

$\begin{array}{lll}4.1 .2 & \text { Zender B } & 15\end{array}$

$\begin{array}{lll}4.2 & \text { Lang lopende proef op het Kanaal } & 16\end{array}$

$\begin{array}{lll}4.2 .1 & \text { Zender C (Noord) } & 16\end{array}$

$\begin{array}{ll}\text { 4.2.2 Zender D (Zuid) } & 17\end{array}$

$\begin{array}{lll}4.3 & \text { Kort lopende proef kanaal } & 18\end{array}$

$\begin{array}{lll}4.3 .1 & \text { Detectie bereik van zenders } & 19\end{array}$

$\begin{array}{lll}\text { 4.3.2 Scheepvaart tijdens kort lopende proef } & 29\end{array}$

5 Conclusie, discussie en aanbevelingen 33

5.1 Ontvangstverschil ontvanger 1 en 2 met zender A en B 33

5.2 Ontvangst zender A en B op ontvanger 4

$\begin{array}{lll}5.3 & \text { Detectie range en belemmering scheepvaart } & 34\end{array}$

$\begin{array}{lll}5.4 & \text { Conclusie } & 36\end{array}$

$\begin{array}{lll}5.5 & \text { Aanbevelingen } & 37\end{array}$

$\begin{array}{llr}6 & \text { Kwaliteitsborging } & 39\end{array}$

$\begin{array}{lr}\text { Literatuur } & \mathbf{4 0}\end{array}$

$\begin{array}{lr}\text { Verantwoording } & 41\end{array}$

$\begin{array}{lr}\text { Bijlage } 1 & 43\end{array}$ 


\section{Samenvatting}

Het Noordzeekanaal is een belangrijke migratieroute voor vis en staat in verbinding met een groot achterland. De regionale waterbeheerders en andere partners rondom het Noordzeekanaal zetten zich in voor een goede bereikbaarheid van de regio voor trekvis. Hierbij wordt samengewerkt binnen het project Ecologische Verbindingszone Noordzeekanaal en Ommelanden.

Het doel van deze studie is het testen van de bruikbaarheid van akoestische telemetrie op het Noordzeekanaal en aanbevelingen te geven voor factoren die een optimale opzet van een detectienetwerk garanderen ter voorbereiding op een grootschalig schieraal uittrek onderzoek in het najaar van 2017. De uitgevoerde studie betreft onderzoek naar de reikwijdte van de signalen en de verstoring door omgevingsfactoren op het signaal.

Binnen deze pilotstudie zijn drie experimenten in 2016 uitgevoerd. De proeven hadden tot doel te beoordelen of de techniek van akoestische telemetrie geschikt is om in te zetten nabij het druk bevaren zeesluiscomplex. Een kort lopende proef met twee velddagen is uitgevoerd, waarbij met een diepe en een ondiepe zender (VEMCO zender type V9) gevaren is op het kanaal in een gebied met meerdere VEMCO VR2W ontvangers langs de oever. Daarnaast zijn er twee langer lopende proeven van enkele weken uitgevoerd, waarvan één nabij de Middensluis en één op het Noordzeekanaal. Ook hier zijn twee zenders en meerdere ontvangers gebruikt om te bepalen of de te verwachte detecties overeen kwamen met de werkelijke detecties. Binnen de proef is onderscheid gemaakt tussen een de (mis)detectiekans van één enkel signaal van een zender en daarnaast de kans dat een schieraal met een zender een detectiestation ongedetecteerd zou kunnen passeren (meerdere signalen). In de praktijk bevindt een gezenderde schieraal zich langere tijd in een veld waarbij meerdere signalen zouden kunnen worden opgepikt door de ontvangers. In dit laatste geval geldt een misdetectie wanneer alle uitgezonden signalen binnen het bereik van het detectiestation bevond niet worden gedetecteerd.

Uit de pilotstudie blijkt dat de VEMCO techniek bruikbaar is met een verwaarloosbare misdetectiekans voor een studie naar de uittrek van schieraal. Het bereik van de V9 VEMCO zenders op het kanaal is dermate groot, lopend tot in de 100-en meters, dat er voldoende kans is op detectie van passerende schieralen. De kans op misdetectie door invloeden van met name scheepvaart is gering.

Voor het gebruik van VEMCO-telemetrie voor onderzoek naar de uittrek van schieraal worden de volgende aanbevelingen gedaan:

- Vermijdt plaatsing van ontvangers nabij damwanden;

- Het heeft de voorkeur om een dubbele bezetting van ontvangers aan de zeezijde nabij het sluizencomplex te plaatsen om misdetectie te voorkomen;

- Het plaatsen van referentie tags is aan te bevelen om een eventuele misdetectiekans in te schatten;

- $\quad$ Enkele bezetting van ontvangers aan de binnenzijde van het zeesluizen/spui/maalcomplex;

- Dubbele bezetting van ontvangers op het Noordzeekanaal zelf;

- Het aantal signalen per tijdseenheid van de zenders moet hoog zijn (1 signaal per ca. 30-40 $\mathrm{sec}$ ). De kans op misdetectie met een V9 zender wordt hiermee op $<0.00 \%$ ingeschat, gezien het grote bereik van de zenders. De batterijduur moet bij voorkeur minimaal 5 tot 6 maanden aangehouden worden om eventueel laat vertrekkende alen te kunnen detecteren. 


\section{$1 \quad$ Inleiding}

Het Noordzeekanaal is een belangrijke migratieroute voor vis en staat in verbinding met een groot achterland. De regionale waterbeheerders en andere partners rondom het Noordzeekanaal zetten zich in voor een goede bereikbaarheid van de regio voor trekvis. Hierbij wordt samengewerkt binnen het project Ecologische Verbindingszone Noordzeekanaal en Ommelanden.

De komende jaren zal gezamenlijk met de waterschappen onderzoek worden gedaan naar vismigratie in het Noordzeekanaalgebied, gericht op de uittrek van schieraal en de intrek van driedoornige stekelbaars en glasaal. De aanleg van de nieuwe zeesluis in IJmuiden inclusief antiverziltings-maatregelen en de voorbereiding van de vervangingsopgave van het gemaal in IJmuiden vormen voor Rijkswaterstaat (WNN) een belangrijke reden om onderzoek te doen naar de uittrek van schieraal en naar het gedrag van de schieraal bij de passage van de zeesluizen/spui/maalcomplex in IJ muiden. De eerstvolgende jaren is gericht op het vaststellen van een nulsituatie, na 2019 zal de situatie na realisatie van de nieuwe zeesluis worden onderzocht. De resultaten kunnen aanleiding zijn tot het nemen van aanvullende beheermaatregelen voor de trekvis en ze zijn van invloed op de eisen die worden gesteld bij de vervangsopgave van het gemaal.

In het najaar van 2017 is, in samenwerking met de waterschappen, onder meer gedragsonderzoek aan schieraal gepland nabij de boezemgemalen en het complex in IJmuiden met gebruikmaking van akoestische telemetrie. Voorafgaand aan deze experimenten is de onderhavige pilot-studie opgezet om te verkennen wat de mogelijkheden zijn voor het gebruik van akoestische telemetrie in het druk bevaren Noordzeekanaal en zeesluiscomplex. Binnen deze studie is samengewerkt met Visserij Service Nederland. 


\section{Kennisvraag en doel}

De kennisvraag voor deze pilot studie is:

\section{Is akoestische telemetrie, waarbij gebruik gemaakt wordt van VEMCO apparatuur geschikt om toe te passen op het Noordzeekanaal voor de uittrek van schieraal? Zo ja, met welke factoren moet rekening gehouden worden?}

Het doel van deze studie is het testen van de bruikbaarheid van akoestische telemetrie op het Noordzeekanaal ter voorbereiding op een grootschalig onderzoek naar de uittrek van schieraal in het najaar van 2017. Het betreft de reikwijdte van de signalen en eventuele verstoring door scheepvaart of andere structuren op het signaal.

Op basis van de uitgevoerde proeven worden aanbevelingen gedaan welke factoren van belang zijn en op welke wijze de detectiekans kan worden geoptimaliseerd. Hierbij is het goed om onderscheid te maken tussen 1) de (mis) detectiekans van een enkel signaal van een zender en 2) de kans dat een gezenderde schieraal een detectiestation ongedetecteerd kan passeren (dan moeten alle signalen zijn gemist die zijn uitgezonden terwijl de schieraal zich binnen het bereik van het detectiestation bevond). 


\section{Methode}

\subsection{Opstelling ontvangers en zenders}

Om de kennisvraag te beantwoorden zijn drie experimenten uitgevoerd:

1) Langer lopende proef nabij de Middensluis: 22 november - 13 december 2016

2) Langer lopende proef nabij de veerpont op het kanaal bij Velsen: 7 - 13 december 2016

3) Kort lopende proef op het kanaal: 1 en 7 december 2016

Het doel van de kortlopende studie is vooral om de reikwijdte van de zenders naar de ontvangers in te schatten ('detection range'). Het doel van de langer lopende studie is voornamelijk om de invloed van scheepvaart in te schatten en daarnaast de invloed van damwanden en andere obstakels op het signaal inzichtelijk te krijgen (kans op misdetectie van een enkel signaal).

Met deze proeven wordt de detectiekans per uitgezonden signaal van VEMCO V9 zenders getest in relatie tot de lokale omstandigheden (damwanden, scheepvaart etc.) inclusief de omvang van het studiegebied.

\subsection{Langer lopende proef}

Op 22 november 2016 zijn 13 VEMCO-ontvangers (type: VR2W) geplaatst. Tevens zijn er op 22 november 2 zenders bij de Middensluis en op 7 december 2 zenders langs het Noordzeekanaal geplaatst voor de langer lopende proef (zender A-D in 3.1 en Figuur 3.2). De zenders zijn geplaatst aan een touw (Foto 1 ) en dat touw is bevestigd aan een damwand ( $A$ ) of aan een boei (B). Zowel de zenders als de ontvangers zijn op 1-2m diepte vanaf het wateroppervlak geplaatst. De ontvangers 7, 8, 9, 11, 12, 14 en 15 zijn geplaatst aan fuikpalen (Foto 2), ontvangers 1, 2, 10 en 13 zijn bevestigd aan een damwand en ontvangers 3 en 4 zijn geplaatst aan een drijvende boei. Zie tabel 3.1 voor een overzicht van de plaatsing. 


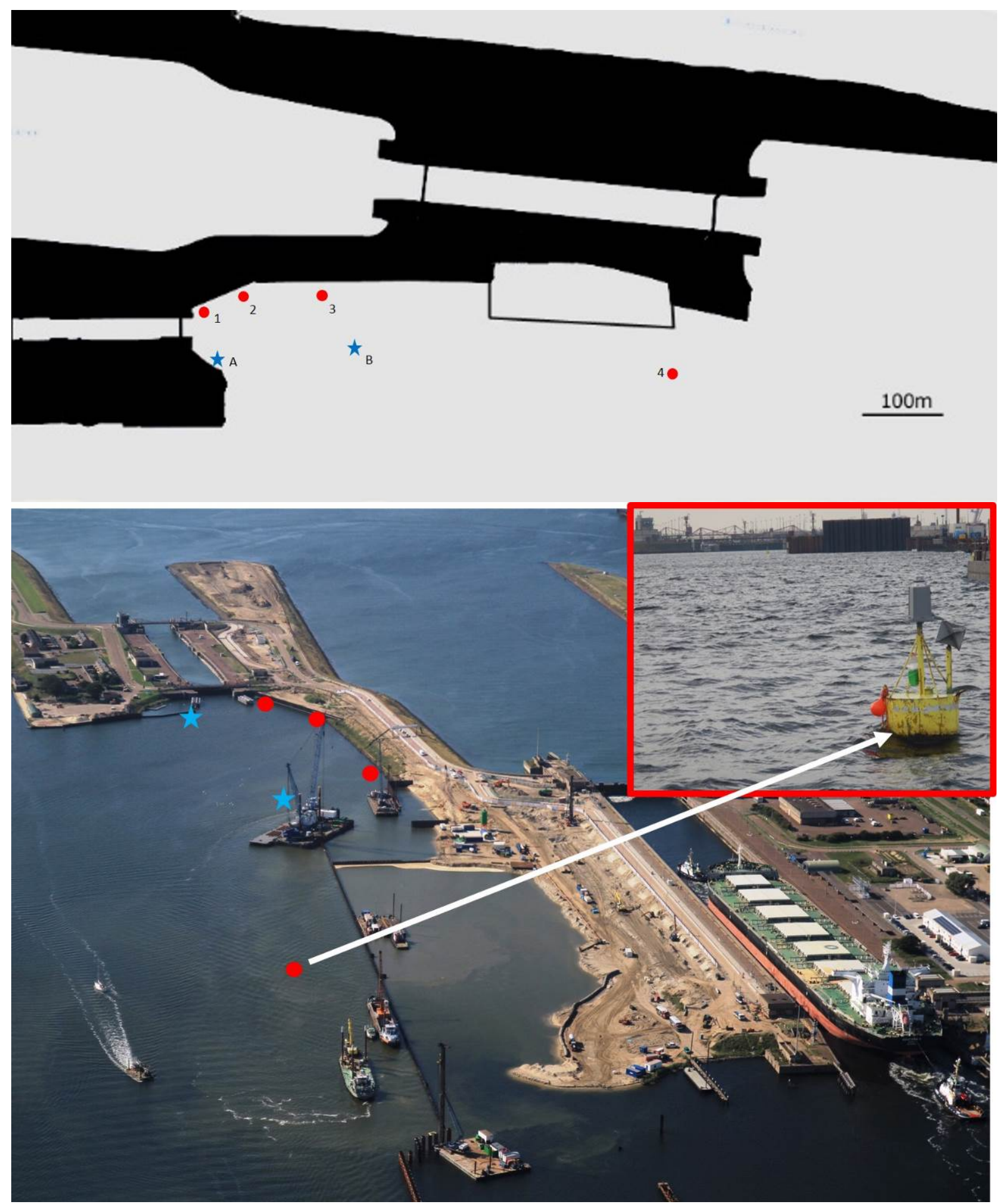

Figuur 3.1 De locaties van vier VR2W ontvangers en twee zenders (A en B) voor het testen van de VEMCO techniek in het Noordzeekanaal nabij de Middensluis. 


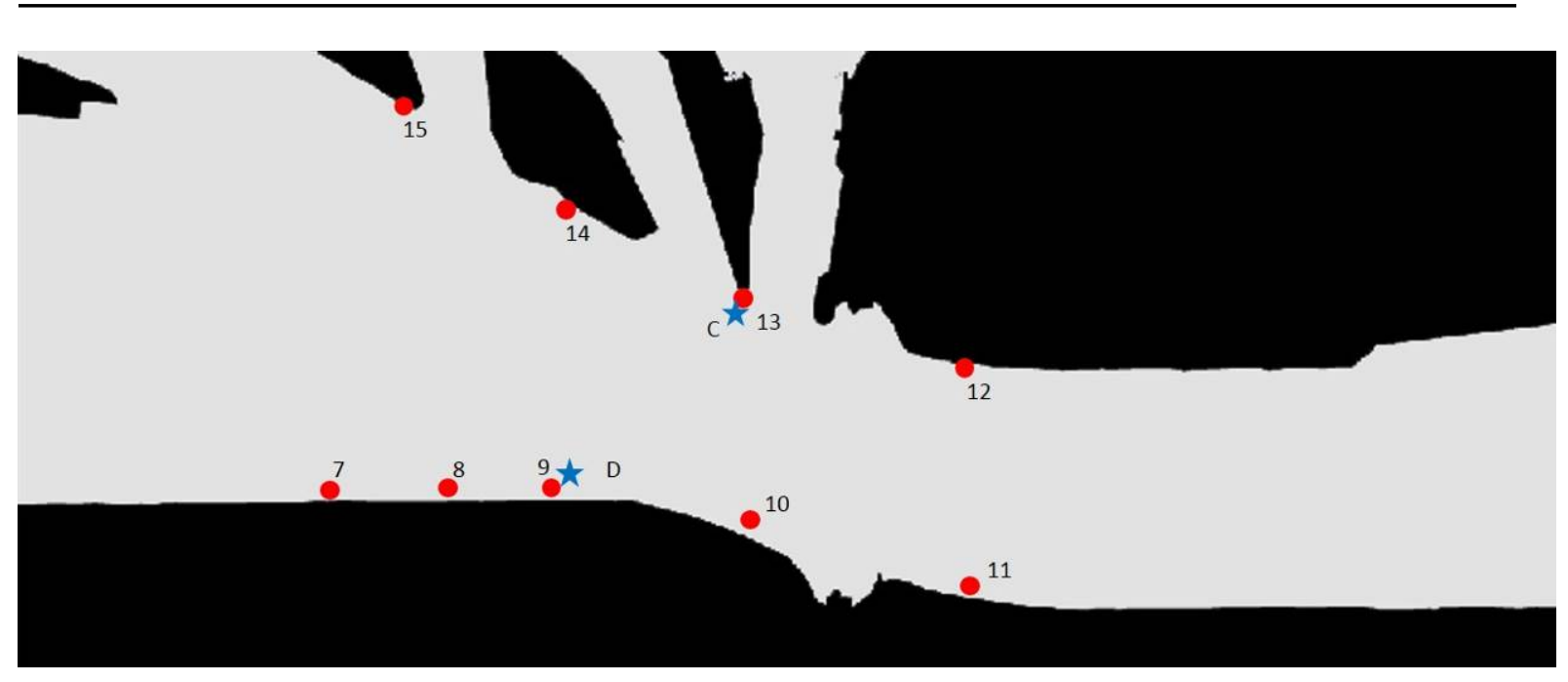

Figuur 3.2 De locaties van negen VR2W ontvangers en twee zenders ( $C_{\text {lang }}$ en $D_{\text {lang }}$ ) voor het testen van de VEMCO techniek in het Noordzeekanaal. Voor de korte termijn proef zijn de zender $C_{\text {kort }}$ en $D_{\text {kort }}$ aan een touw bevestigd welke werd voortgetrokken door een boot.

Tabel 3.1 Een overzicht van de ontvangers en zenders met locatie en bevestigingsmiddel

\begin{tabular}{|c|c|c|c|c|c|}
\hline ontvanger & locatie & bevestiging & zender & locatie & bevestiging \\
\hline 1 & Middensluis & damwand & $A$ & Middensluis & damwand \\
\hline 2 & Middensluis & damwand & B & Middensluis & boei \\
\hline 3 & Middensluis & boei & $C_{\text {kort }}$ & Kanaal (veerpont) & touw \\
\hline 4 & Middensluis & boei & $D_{\text {kort }}$ & Kanaal (veerpont) & touw \\
\hline 7 & Kanaal & fuikpaal & $C_{\text {lang }}$ & Kanaal & damwand \\
\hline 8 & Kanaal & fuikpaal & $D_{\text {lang }}$ & Kanaal & fuikpaal \\
\hline 9 & Kanaal & fuikpaal & & & \\
\hline 10 & Kanaal & damwand & & & \\
\hline 11 & Kanaal & fuikpaal & & & \\
\hline 12 & Kanaal & fuikpaal & & & \\
\hline 13 & Kanaal & damwand & & & \\
\hline 14 & Kanaal & fuikpaal & & & \\
\hline 15 & Kanaal & fuikpaal & & & \\
\hline
\end{tabular}




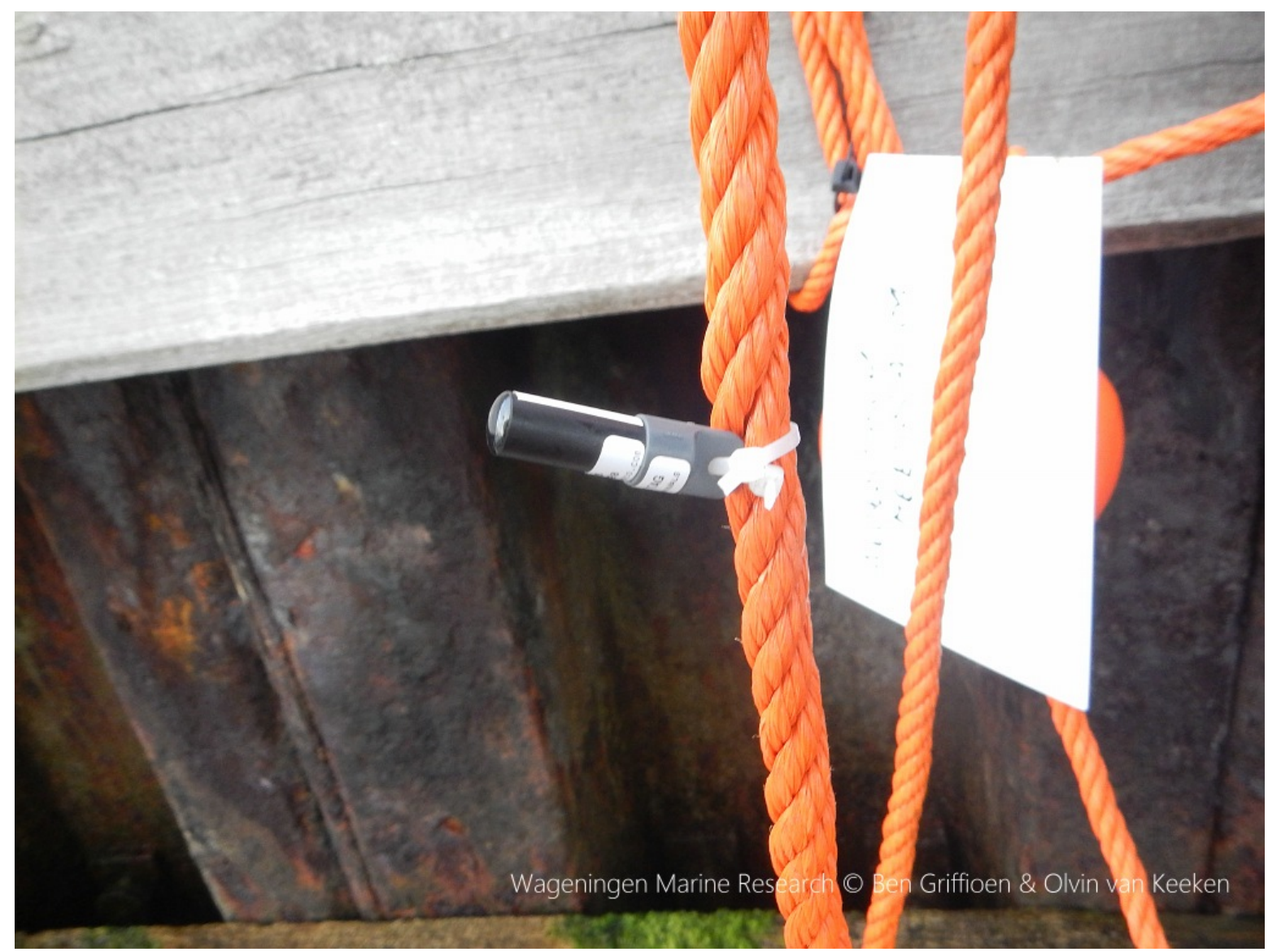

Foto 1. Een zender $C_{\text {lang }}$ aan een touw voor de lange termijn proef bij locatie nr.13 (damwand). De zender hangt onderwater voor de uitvoering van de proef.

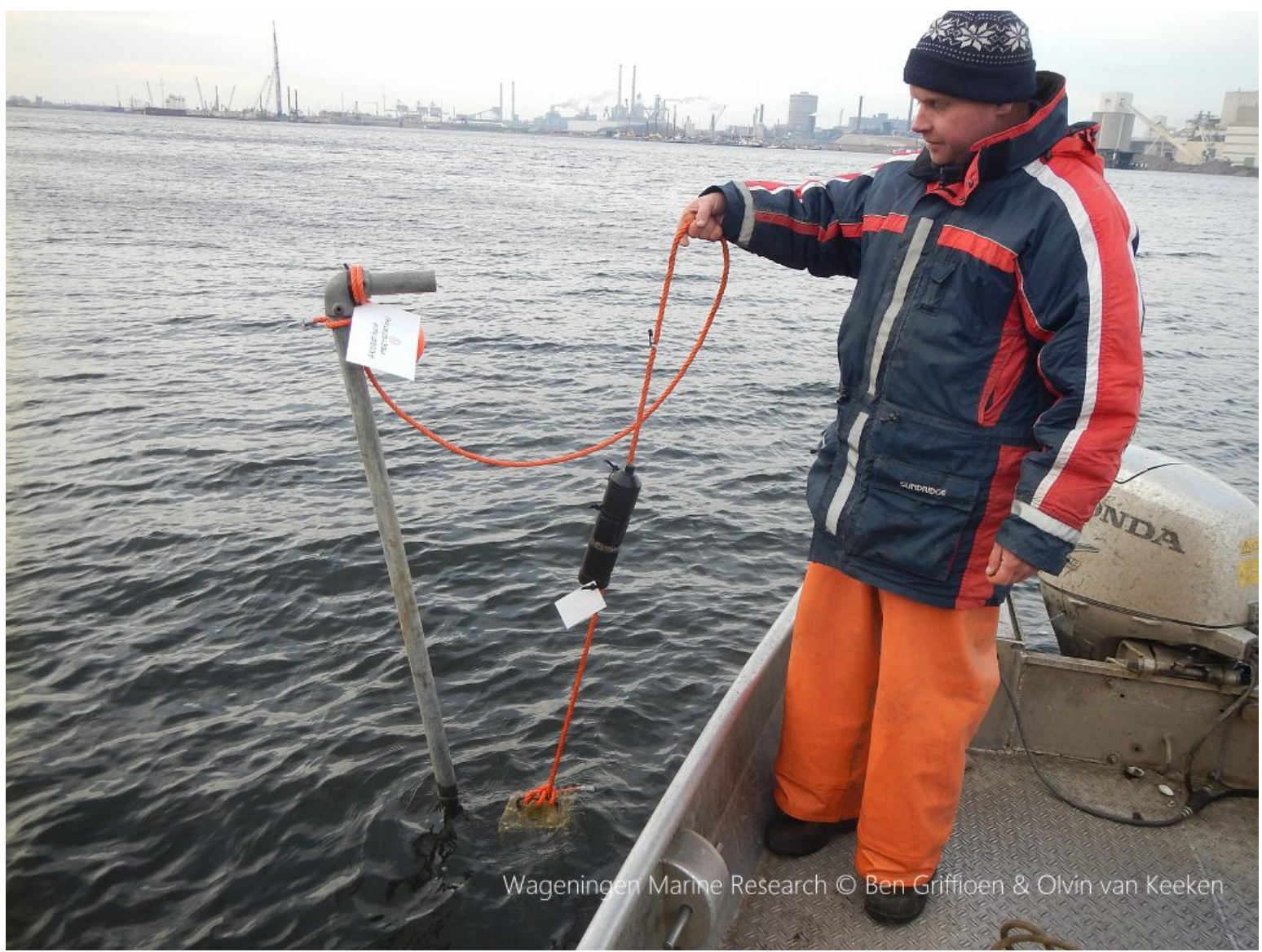

Foto 2 . Een locatie met een ontvanger die middels een fuikpaal, touw en gewicht op locatie blijft. 


\subsection{Kort lopende proef}

Voor de kort lopende proef is met twee velddagen (1 december 9:04 - 15:22 en 7 december 10:03 14:23) respectievelijk 24 en $20 \mathrm{~km}$ afgelegd op het kanaal met twee zenders aan een touw met gewicht hangend vanaf een boot (Figuur 3.3 en 3.4). Eén zender hing op circa $2 \mathrm{~m}$. diepte en één op circa $10 \mathrm{~m}$. diepte. Er is gevaren met een snelheid tussen de $3-4 \mathrm{~km} / \mathrm{uur}(0,8-1,1 \mathrm{~m} / \mathrm{s})$.

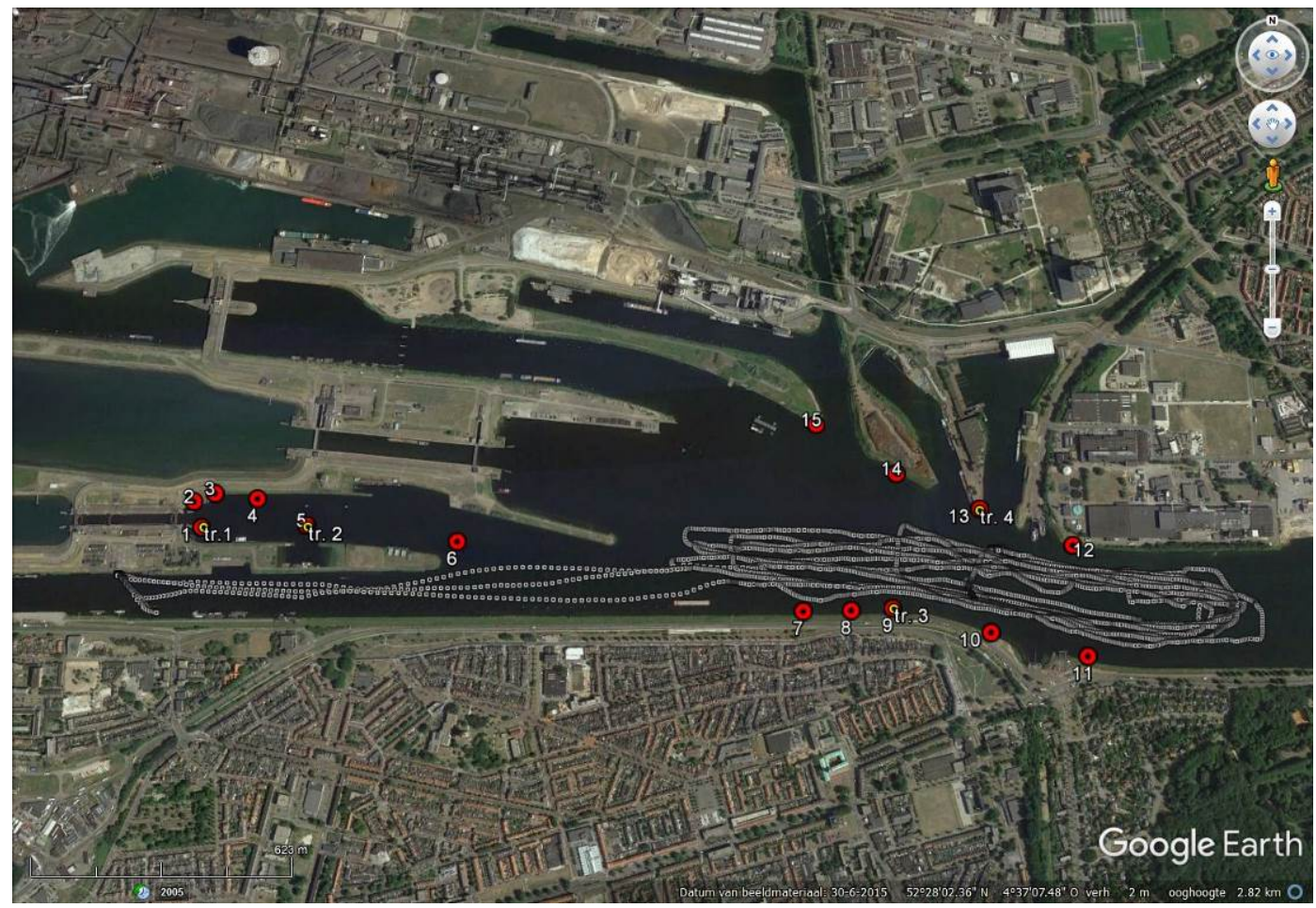

Figuur 3.3 Vaarbeweging van de onderzoeksboot op 1 december.

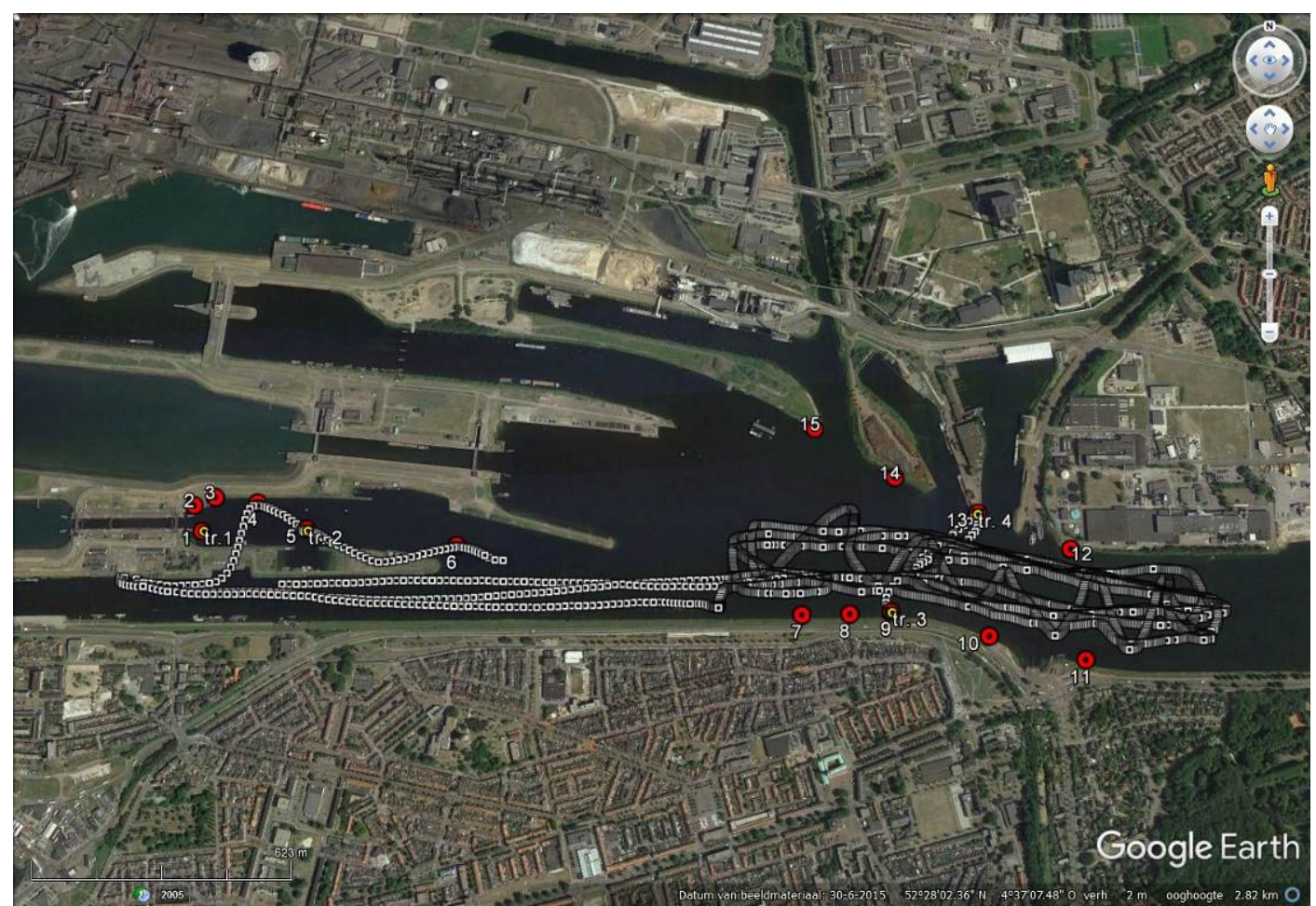

Figuur 3.4 Vaarbeweging van de onderzoeksboot op 7 december. 


\subsection{Techniek}

\subsubsection{Werking VEMCO techniek}

Voor de proef zijn 13 VR2W ontvangers gebruikt. De twee zenders (V9 ${ }^{1}$ ) voor de lang lopende proef nabij de Middensluis gaven om de 30 seconden een signaal met een unieke code af. Omdat twee zenders nabij elkaar waren geplaatst, was het van belang dat na verloop van tijd geen overlap ontstond in de detectie. De tweede zender werd circa 15 seconden na de eerste zender geactiveerd (halverwege $30 \mathrm{sec}$.). Op deze manier ontstond gedurende de proef geen zogenaamde 'spookdetecties' veroorzaakt door een overlap in het uitgezonden signaal ('signal collision'). Voor de korte termijnproef is een verschil in uitzendtijd tussen beide zenders van circa 12 seconden gebruikt om de frequentie van data zo hoog mogelijk te houden tijdens de kort lopende proef.

VEMCO zenders werken op basis van het uitzenden van een serie (puls-trein) van $69 \mathrm{kHz}$ geluiden (signalen) met een digitale code voor elke zender. In de huidige studie heeft de puls-trein 8 geluiden uitgezonden in circa 2.6 seconden, gevolgd door een periode waarbij geen geluid uitgezonden wordt ( 12 en 30 seconden interval). In de VR2W ontvanger is een algoritme geïnstalleerd dat zoekt naar een serie van acht geluidspulsen met een bepaald interval tussen de onderlinge pulsen. Indien de ontvanger deze acht geluidspulsen registreert, waarbij het interval tussen elke twee pulsen dat geregistreerd wordt door de ontvanger binnen de vastgestelde grenzen van het algoritme zit, dan wordt dit als een detectie door de ontvanger geregistreerd. Elke serie van geluiden die het algoritme in de ontvanger registreert, begint met twee geluiden die binnen een bepaalde interval moeten zitten; het SYNC interval.

In Figuur 3.5 is de bovenste regel een werkelijke detectie met acht geluidspulsen. In de tweede regel zijn akoestische verstoringen van buitenaf weergegeven. Indien deze verstoringen tegelijk plaatsvinden met het uitzenden van een akoestisch signaal van de zender, wat plaatsvindt in de derde regel, wordt wel een Sync interval gestart door de ontvanger (deze gaat zoeken naar acht geluiden op bepaalde intervallen van elkaar). Echter omdat niet de acht pulsen op de juiste intervallen van elkaar ontvangen worden na het eerste Sync interval, kan de ontvanger geen detectie maken. Het interval tussen geluid vier en vijf is te kort en wordt door het algoritme in de ontvanger verstoten en de registratie om tot acht geluiden te komen stopt. Vervolgens volgen weer twee geluidpulsen binnen het juiste interval voor een Sync en gaat de ontvanger weer op zoek naar in totaal acht geluiden op juiste onderlinge intervallen om te komen tot een detectie. Een ontvanger registreert per dag het aantal SYNC's, het totaal aantal signalen en of een detectie van acht geluidspulsen kan worden omgezet in een werkelijke detectie, of als foute detectie geweigerd wordt op basis van een foutencontrole in het algoritme van de ontvanger.

\footnotetext{
${ }^{1}$ Een V7 zender heeft beperktere batterijduur en detectie range ten opzichte van een V9 zender bij een vergelijkbare signaal interval. De detectie range is afhankelijk van lokale omstandigheden. Voor een V7 is dit gemiddeld rond de 100-200 meter, terwijl dit voor een V9 zender gemiddeld rond de 300-500 meter is.
} 


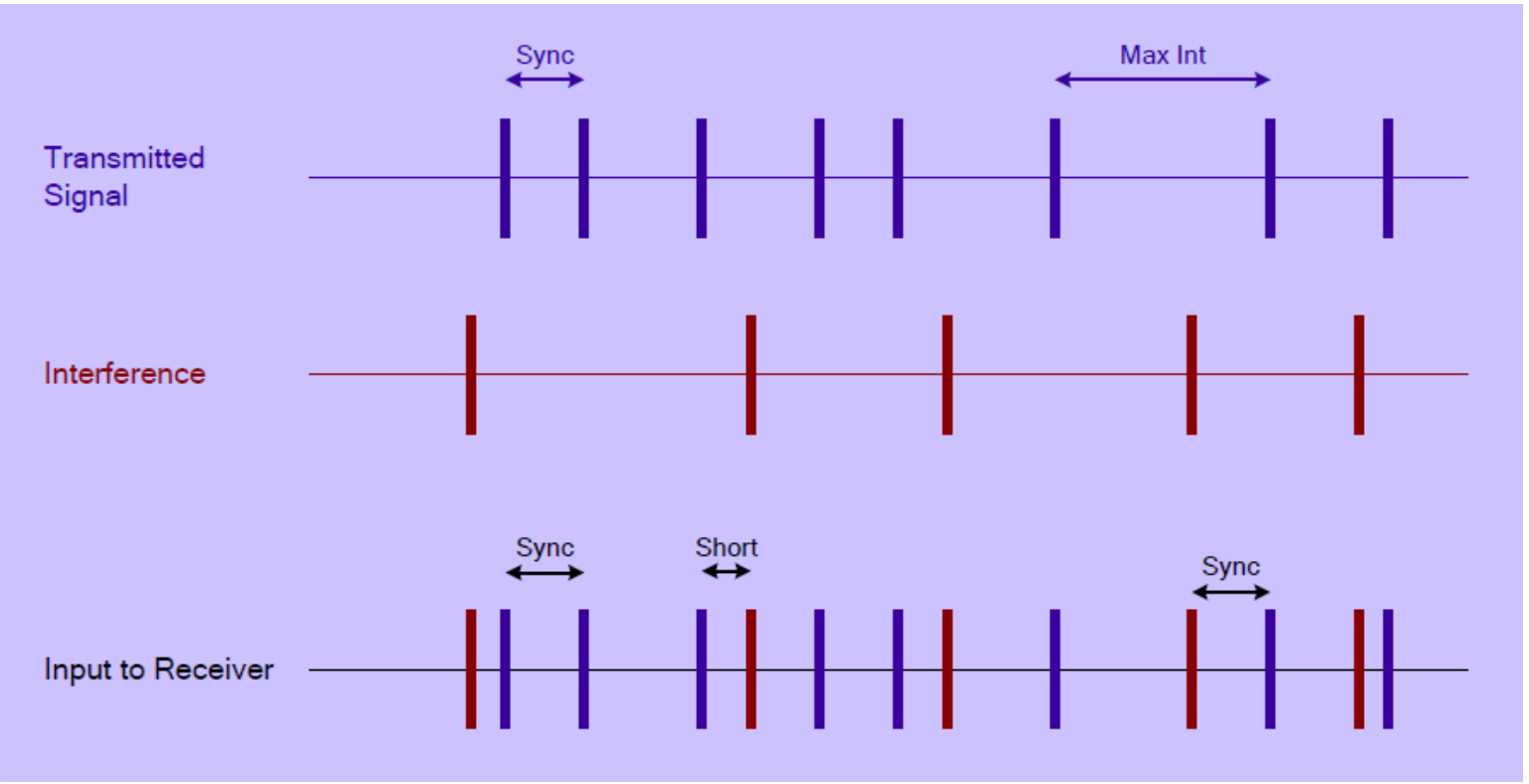

Figuur 3.5 Registratie van een werkelijke detectie en geen mogelijkheid tot detectie wegens verstoring

Naast verstoring door omgevingsgeluid kunnen ook spookdetecties (met een niet bestaand tag nummer als gevolg) ontstaan door het gelijktijdig uitzenden van geluid door twee zenders. In Figuur 3.6 laten de eerste twee regels de puls-treinen van twee zenders zien. In de derde regel overlappen de geluiden van deze zenders en worden geen detecties waargenomen (tag-collision), doordat in dit geval het interval tussen geluid 5 en 6 korter is dan het interval waar het algoritme in de ontvanger naar zoekt.

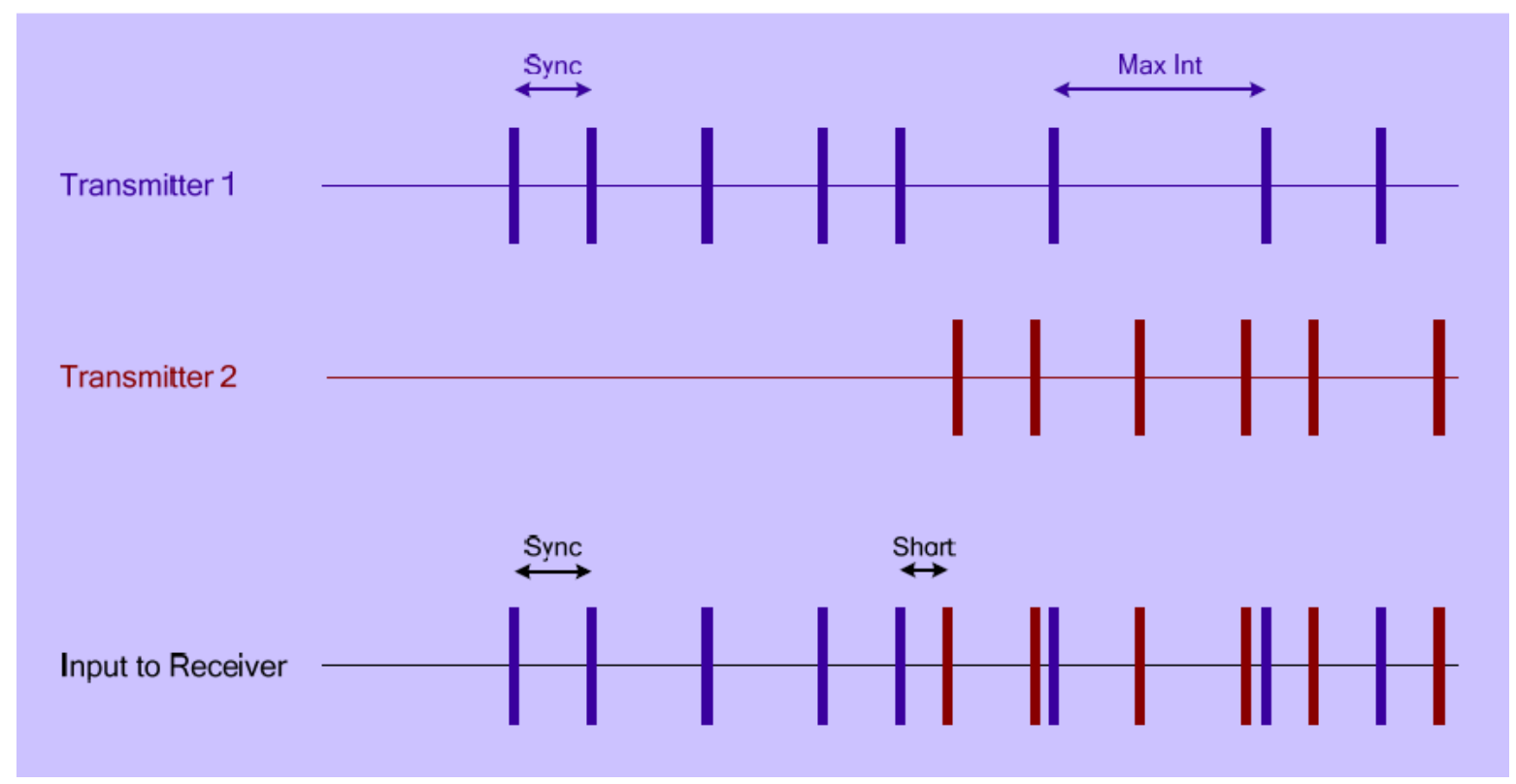

Figuur 3.6 Overlappende intervallen tussen twee zenders. 


\section{Resultaten}

\subsection{Lang lopende proef Middensluis}

\subsubsection{Zender A}

In figuur 4.1 is het percentage werkelijke detecties weergegeven van de door de zender uitgezonden signalen (puls-treinen) per uur van de dag, gemiddeld over de meetperiode. In de figuren staat het maximale aantal detecties gesteld op $100 \%$ op basis van de signaal frequentie en de duur van de proef. $\mathrm{Bij} \mathbf{1 0 0 \%}$ worden alle signalen opgevangen door de ontvangers en vindt er geen enkel misdetectie van een enkel signaal plaats. In werkelijkheid is een succesvolle ontvangst afhankelijk van afstand tussen zender en ontvanger in combinatie met lokale omstandigheden (watertemperatuur, fysieke blokkades, etc.).

Zender A werd beperkt ontvangen met circa $20 \%$ van het maximale aantal detecties bij ontvanger nr. 1 , de meest nabije locatie. Op ontvanger 2 en 3 werd iets meer dan $60 \%$ van de het maximale aantal signalen ontvangen. Bij ontvanger 4 was er een duidelijke dip tussen 08:00 in de ochtend tot aan het einde van de middag (17:00) waarneembaar.
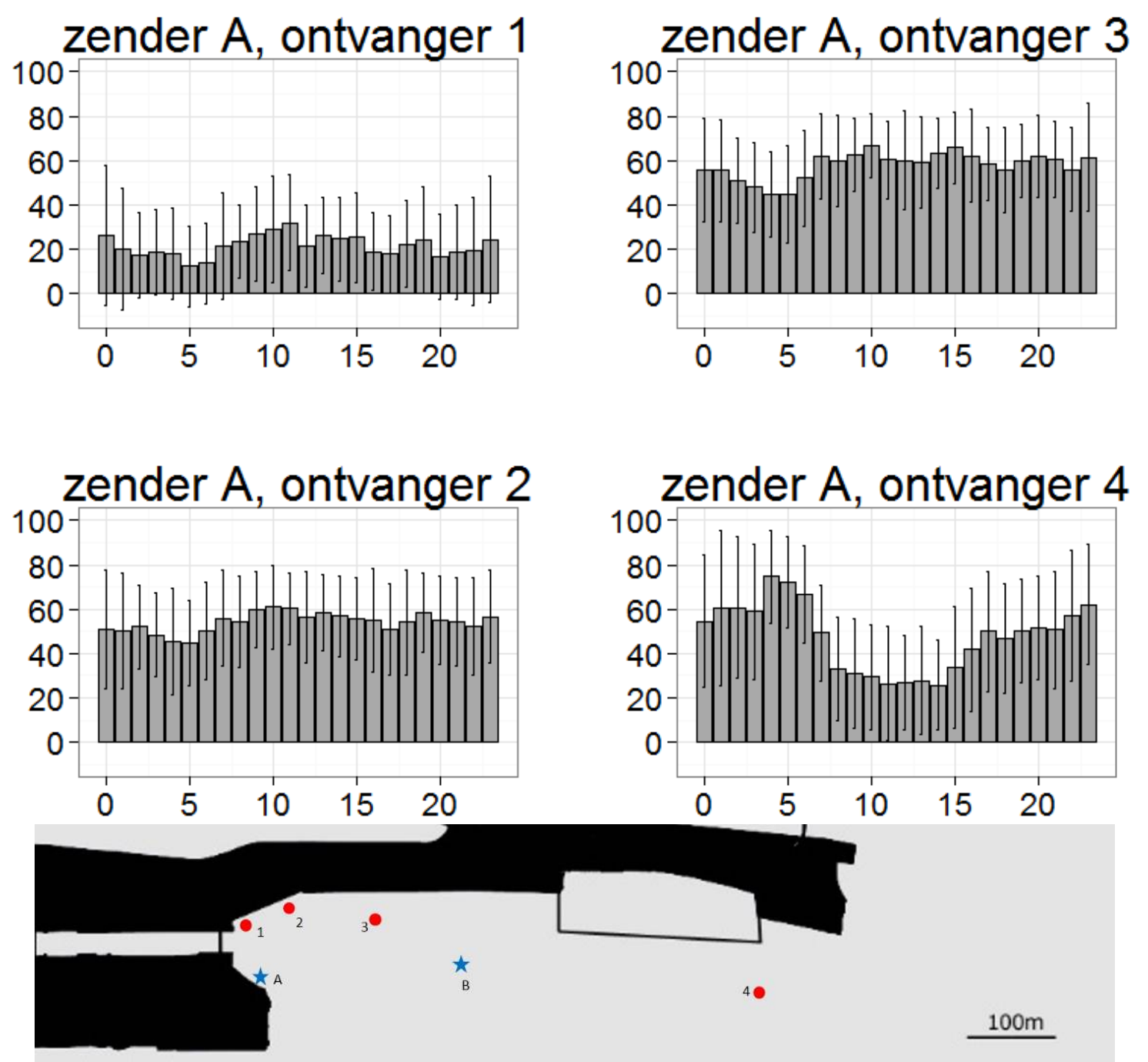

Figuur 4.1 Detecties (\% van het maximale aantal uitgezonden signalen) per uur voor zender $\mathrm{A}$ in het Binnentoeleidingskanaal van de Middensluis. De grafieken geven per ontvanger en per uur de daadwerkelijke detecties weer van de door zender A uitgezonden signalen. De error bars geven de standaard deviatie weer over alle waarneming tussen 22 november en 13 december. 


\subsubsection{Zender B}

Een zelfde analyse is uitgevoerd voor zender B (Figuur 4.2). Zender B werd goed ontvangen door ontvanger 1 en 2 met meer dan $80 \%$ van de uitgezonden signalen. Ontvanger 3 werd ontvangen met circa $60 \%$ van de uitgezonden signalen, terwijl ontvanger 4 een duidelijke dip in ontvangst had tussen 08:00 - 17:00 uur.
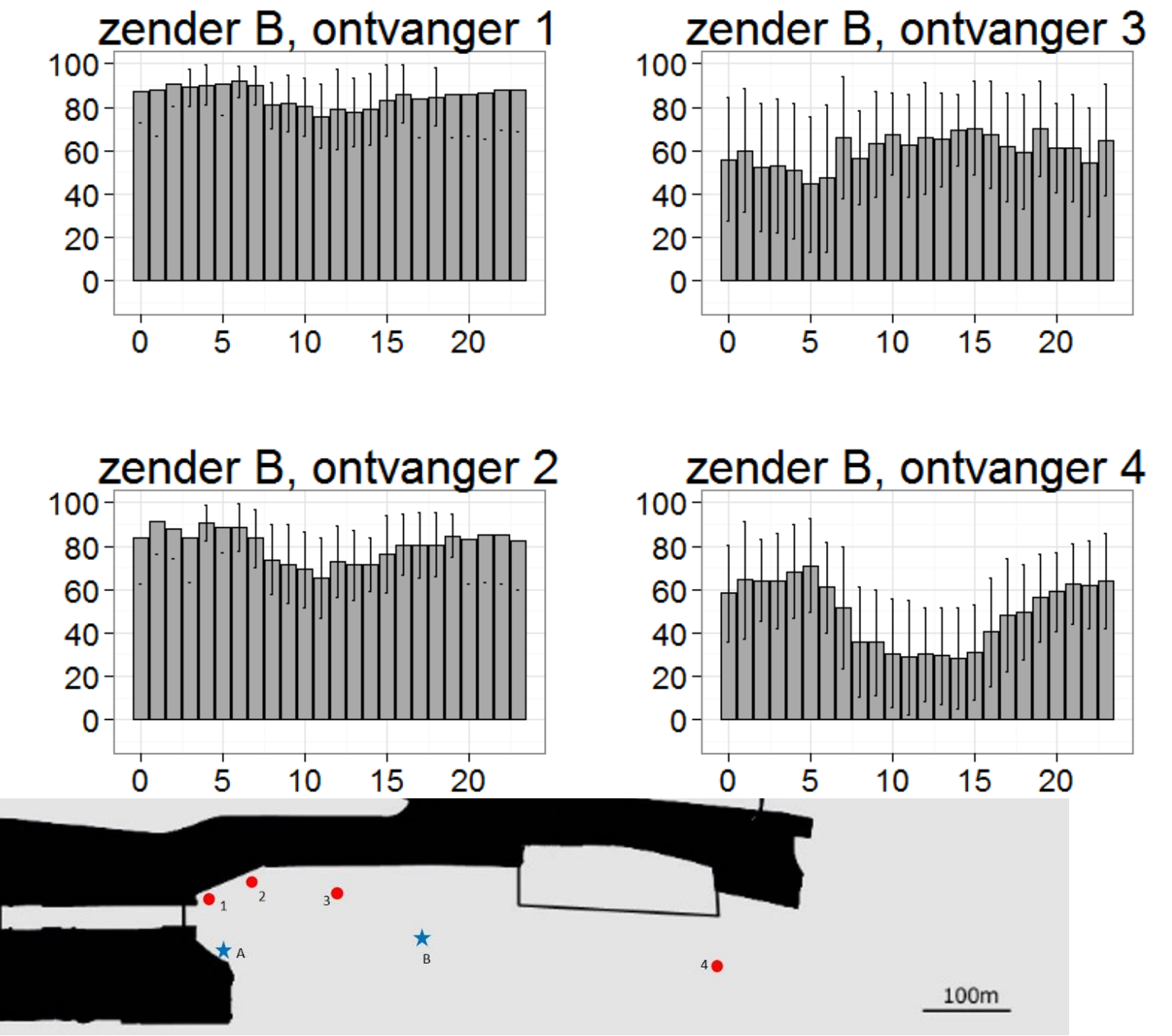

Figuur 4.2 Detecties (\% van het maximale aantal uitgezonden signalen) per uur voor zender B in het Binnentoeleidingskanaal van de Middensluis. De grafieken geven per ontvanger en per uur de daadwerkelijke detecties weer van de door zender B uitgezonden signalen. De error bars geven de standaard deviatie weer over alle waarneming tussen 22 november en 13 december. 


\subsection{Lang lopende proef op het Kanaal}

\subsubsection{Zender C (Noord)}

Bij ontvangers 10 en 11 was een lichte dip zichtbaar overdag (10:00-19:00) voor zender C (Figuur 4.3). De ontvangers 7, 8 en 9 werden beperkt ontvangen, waarbij 7 en 8 een lichte dip overdag vertoonden. De ontvangers 12, 14 en 15 werden niet of nauwelijks ontvangen, mogelijk door een 'dode hoek' in het signaal.
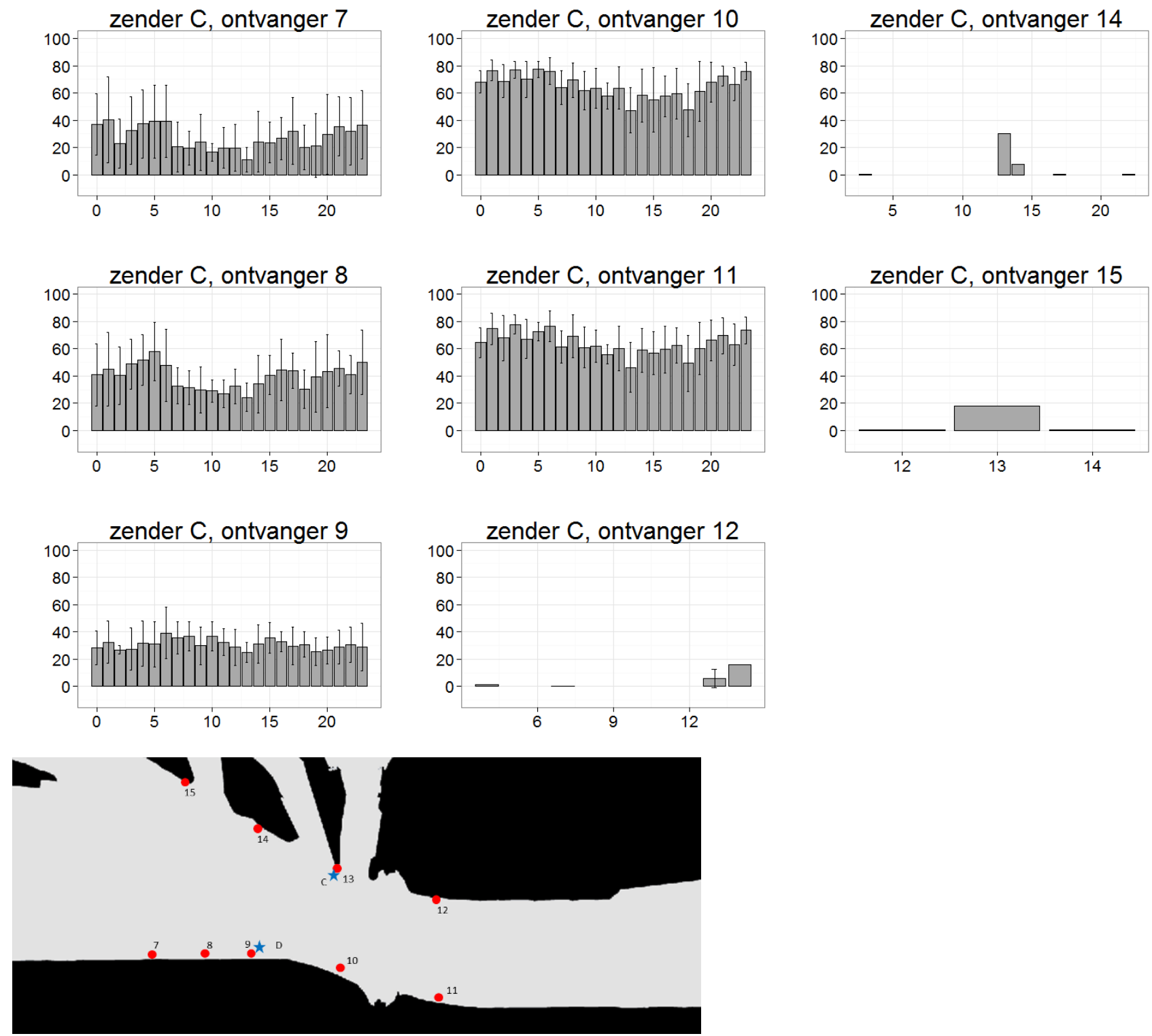

Figuur 4.3 Detecties (\% van het maximale aantal uitgezonden signalen) per uur voor zender C. De grafieken geven per ontvanger en per uur de daadwerkelijke detecties weer van de door zender $\mathrm{C}$ uitgezonden signalen. De error bars geven de standaard deviatie weer over alle waarneming tussen 7 december en 13 december. 


\subsubsection{Zender D (Zuid)}

De zender aan de zuidkant van het kanaal (Figuur 4.4) werd goed ontvangen door ontvangers 13 en 14 die beiden aan de overkant van het kanaal stonden gepositioneerd. De ontvangst was iets minder bij ontvangers 8 en 15. Ontvangers 7 en 12 werden beperkt ontvangen met circa $40 \%$ van de te verwachten signalen. Ontvangers 10 en 11 werden niet of nauwelijks ontvangen, mogelijk door een 'dode hoek' in het signaal.
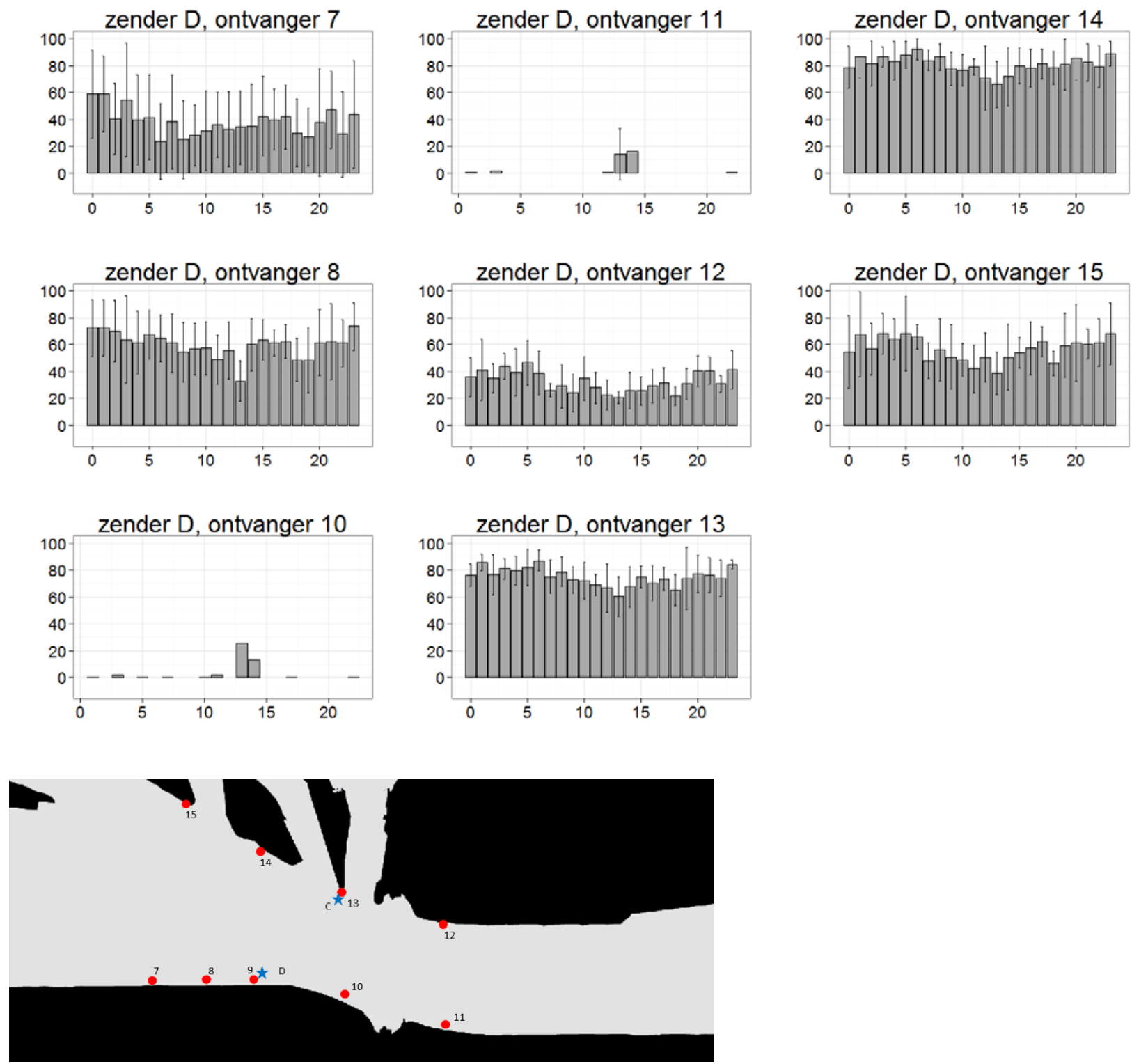

Figuur 4.4 Detecties (\% van het maximale aantal uitgezonden signalen) per uur voor zender D. De grafieken geven per ontvanger en per uur de daadwerkelijke detecties weer van de door zender $D$ uitgezonden signalen. De error bars geven de standaard deviatie weer over alle waarneming tussen 7 december en 13 december. 


\subsection{Kort lopende proef kanaal}

De variatie aan scheepvaart op het Noordzeekanaal is groot (Foto 3 en 4 voor een indruk). Op dag 1 zijn ten tijde van het experiment 71 vaartuigen waargenomen (incl. dubbelingen en veerpont). De lengte en de diepgang van de schepen varieerde van kleine boten van rond de 10 meter tot grote schepen van een kleine 200 meter ('Aquintania' en sleepboten). Op dag 2 zijn ten tijde van het experiment 51 vaartuigen waargenomen (incl. dubbelingen en veerpont). Het grootste schip was naar schatting de 'Cape Star' met rond de $200 \mathrm{~m}$ en een diepgang van $8 \mathrm{~m}$.

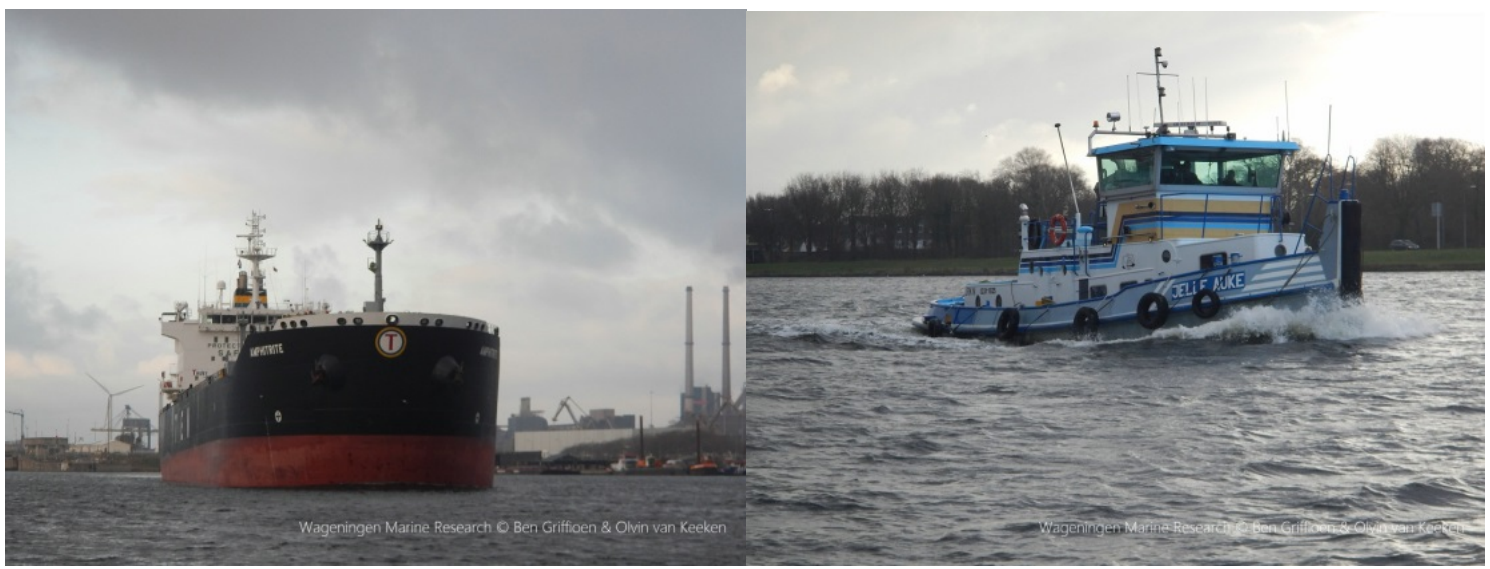

Foto 3. Enkele schepen op het Noordzeekanaal ten tijde van de proef op 1 december 2016.

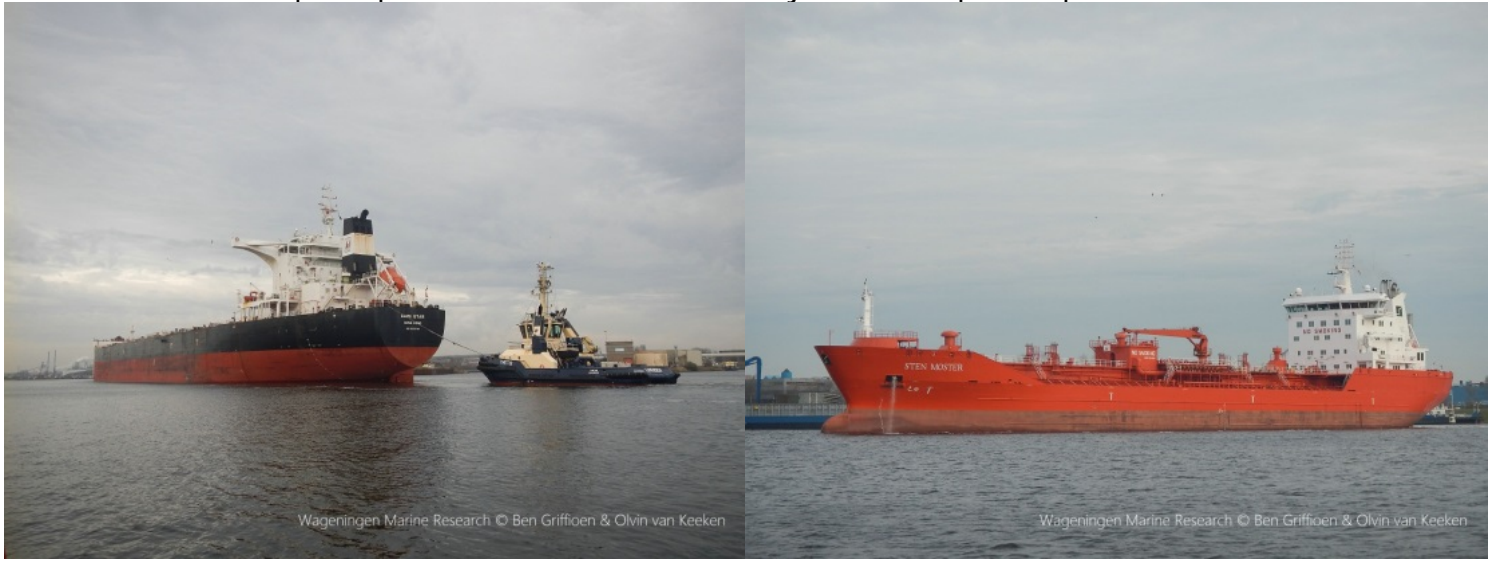

Foto 4. Enkele schepen op het Noordzeekanaal ten tijde van de proef op 7 december 2016 


\subsubsection{Detectie bereik van zenders}

Om een indruk te krijgen wat de detectie afstand was van de zender tijdens de kort lopende proef is het aantal succesvolle detecties afgezet per afstand (Figuur 4.5). Het bereik van ontvangst liep in sommige gevallen op tot boven de 950 meter. De meeste detecties werden waargenomen in het bereik van 50$450 \mathrm{~m}$. De boot met de zender heeft nauwelijks dichter dan $50 \mathrm{~m}$ van de ontvangers gevaren waardoor er nauwelijks detecties zijn van 0-50m.

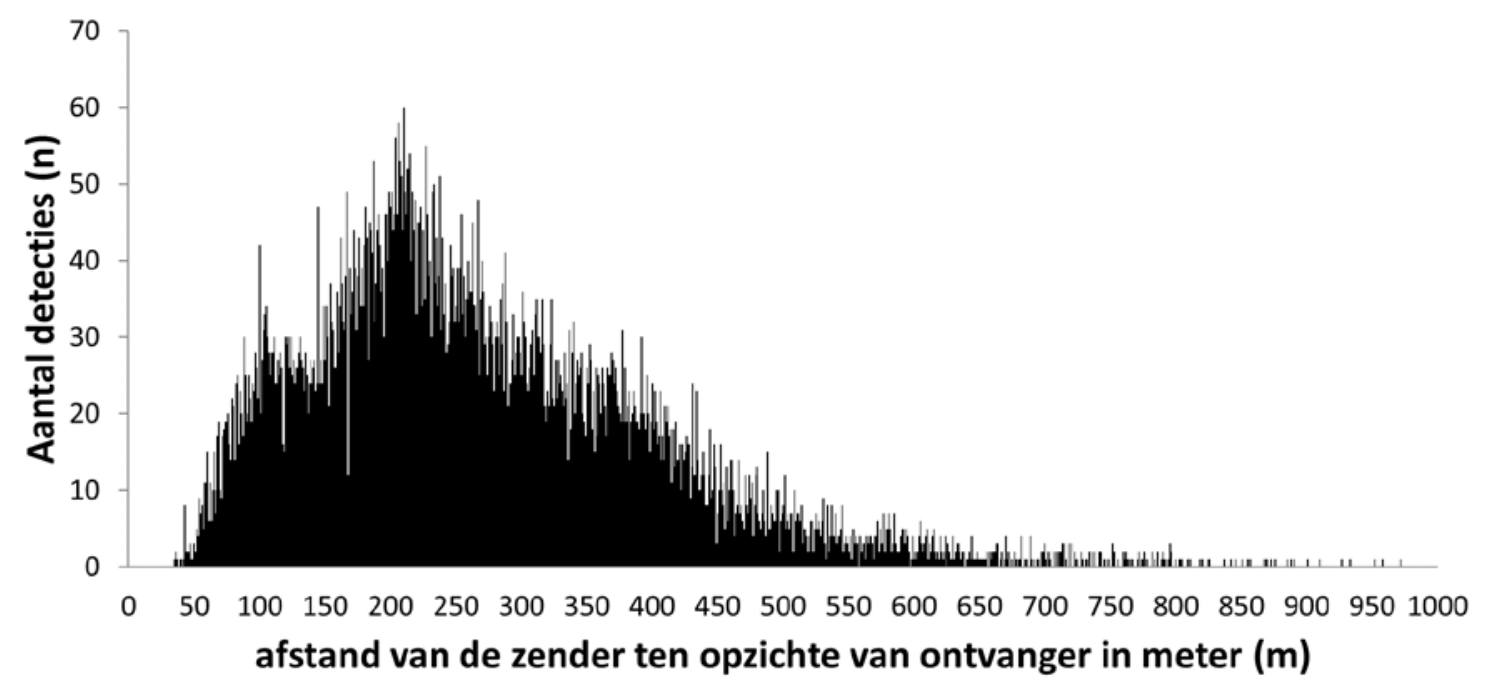

Figuur 4.5 Afstand van een zender ten opzichte van een ontvanger in meter (X-as 0-1000 meter) en het aantal detecties per afstand (Y-as) per locatie ten tijde van de kort lopende proef ( 2 dagen) waarbij gevaren

NB. er is geen gelijke verdeling van kans op detectie per afstand. De figuur geeft een indruk van de reikwijdte van het akoestisch signaal van de ontvangers volgens deze opstelling. In de bijlage staat de detecties per ontvanger.

Om een indruk te krijgen van het detectie veld van een zender voor de verschillende ontvangers is bepaald wat de uiterste detecties zijn geweest per ontvanger voor de diepe en de ondiepe zender (Tabel 4.1). De langst gemeten afstand is ruim 970 meter (ontvanger 7 met de ondiepe zender, zie ook Bijlage 1). Gemiddeld werd in oostelijke richting (van de sluizen af) de ondiepe zender verder ontvangen met 44 meter. Maar de variatie was groot met 106 meter in het voordeel voor de diepe zender (ontvanger 15) tot 204 meter bij ontvanger 9 voor de ondiepe zender. In westelijke richting (richting de sluizen), was het gemiddelde verschil in detectie range tussen de diepe en de ondiepe zender $25 \mathrm{~m}$ in het voordeel van de diepe zender. De variatie was hier van 105 meter in het voordeel van de diepe zender tot 7 meter in het voordeel van de ondiepe zender (ontvanger 13).

Tabel 4.1 Overzicht van uiterste detectie en afstand (meter) tot de ontvanger binnen het gevaren traject. Het verschil in afstand tussen de diepe en de ondiepe zender per ontvanger is in de tabel weergegeven evenals het gemiddelde. NB. Onderlinge afstanden tussen de ontvangers en detecties zijn niet vergelijkbaar. Afstanden zijn gebaseerd op Figuur 4.6.

\begin{tabular}{|c|c|c|c|c|c|c|c|}
\hline & \multicolumn{7}{|c|}{ afstand tot uiterste detectie binnen traject } \\
\hline & & oostel & lijke richting & & weste & lijke richting & \\
\hline & Ontvanger & ondiepe zender & diepe zender & verschil & ondiepe zender & diepe zender & verschil \\
\hline Noord & 15 & 601 & $\begin{array}{r}707 \\
\end{array}$ & -106 & 496 & 492 & 4 \\
\hline Noord & 14 & 711 & 611 & 100 & 570 & 579 & -9 \\
\hline Noord & 13 & 636 & 603 & 33 & 762 & 755 & 7 \\
\hline Noord & 12 & 416 & 496 & -80 & 861 & 966 & -105 \\
\hline Zuid & 11 & 450 & 454 & -4 & 895 & 907 & -12 \\
\hline Zuid & 10 & 670 & 668 & 2 & 540 & 616 & -76 \\
\hline Zuid & 9 & 828 & 624 & 204 & 558 & 555 & 3 \\
\hline Zuid & 8 & 799 & 721 & 78 & 405 & 435 & -30 \\
\hline Zuid & 7 & 977 & 808 & 169 & 306 & 315 & -9 \\
\hline Gemiddelde & & & & 44 & & & -25 \\
\hline
\end{tabular}


De detecties per ontvanger en zender (diep en ondiep) en daarmee het bereik van de zenders is weergegeven Figuur 4.6. Detecties bij ontvangers van de ondiepe zender (circa 2 meter onder het wateroppervlakte) en de diepe zender (circa $10 \mathrm{~m}$ diepte onder het wateroppervlakte) worden getoond voor beide vaardagen samen. De vaarbewegingen zijn met een witte lijn zichtbaar gemaakt.

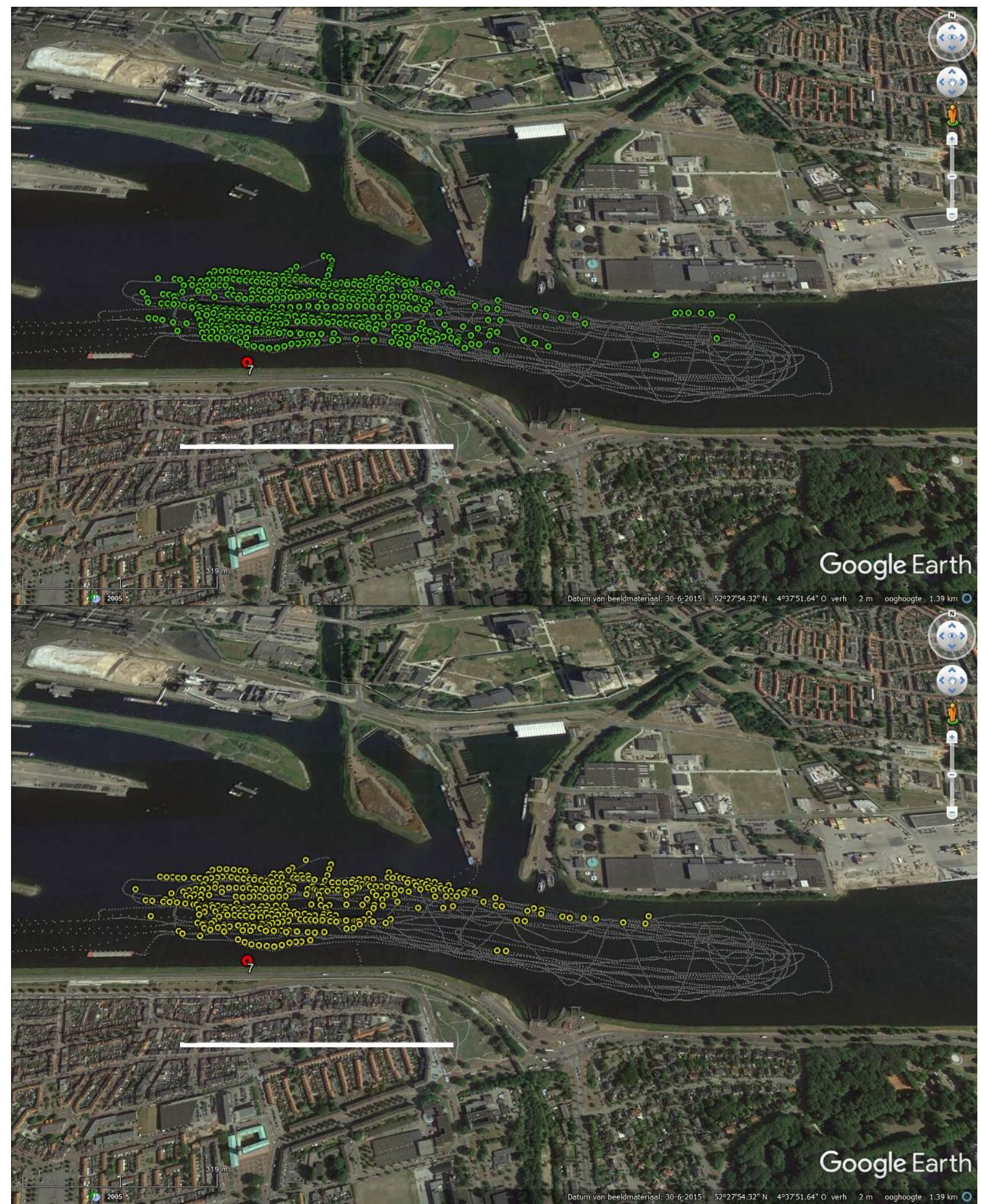

Figuur 4.6 Detecties bij ontvanger 7 (rode punt) van de ondiepe zender (groen, boven) en de diepe zender (geel, onder) tijdens beide vaardagen. De vaarbewegingen zijn met een witte lijn zichtbaar gemaakt. De witte balk in de figuur geeft $500 \mathrm{~m}$ weer. 


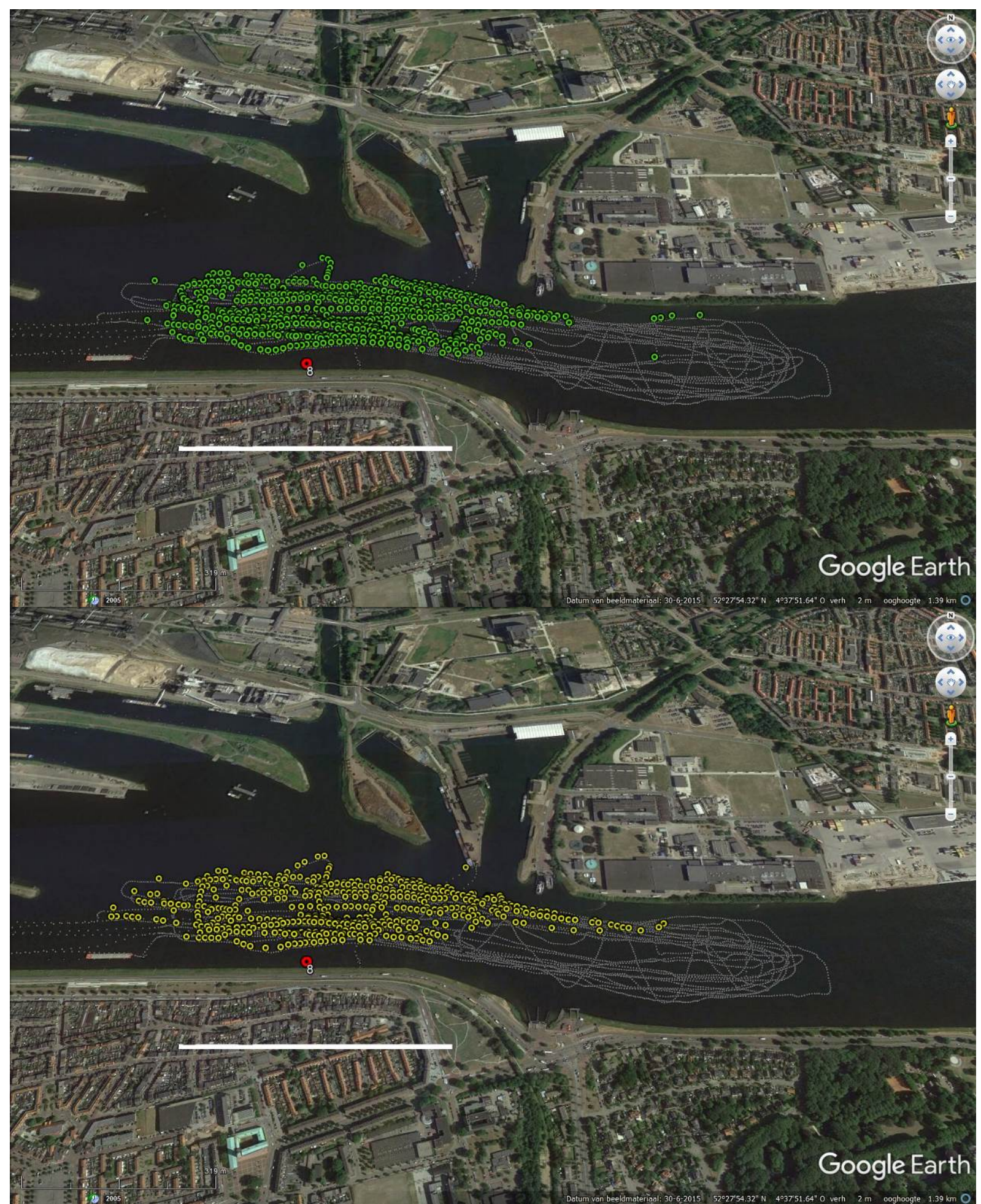

Figuur 4.6 vervolg. Detecties bij ontvanger 8 (rode punt) van de ondiepe zender (groen, boven) en de diepe zender (geel, onder) tijdens beide vaardagen. De vaarbewegingen zijn met een witte lijn zichtbaar gemaakt. De witte balk in de figuur geeft $500 \mathrm{~m}$ weer. 


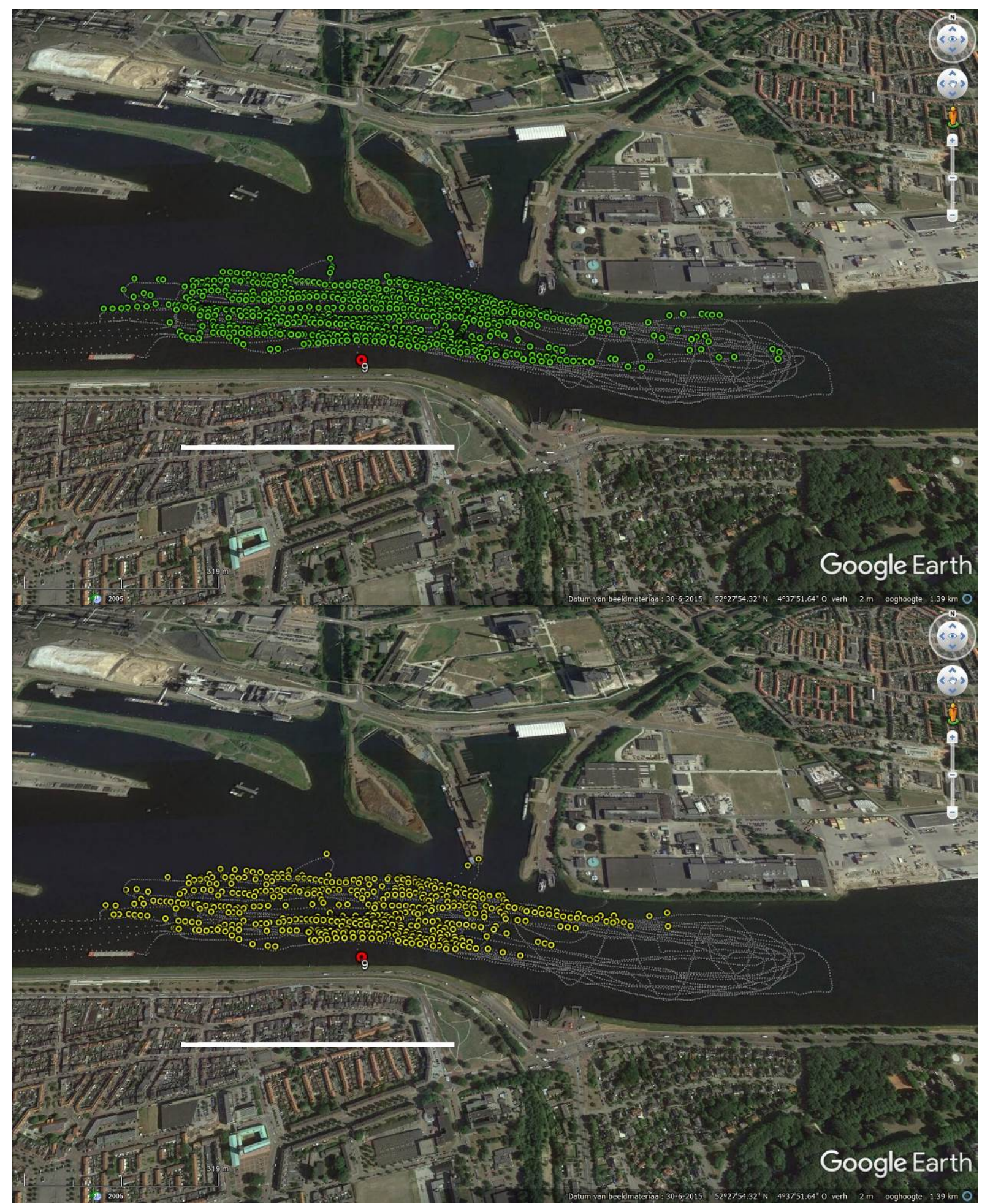

Figuur 4.6 vervolg. Detecties bij ontvanger 9 (rode punt) van de ondiepe zender (groen, boven) en de diepe zender (geel, onder) tijdens beide vaardagen. De vaarbewegingen zijn met een witte lijn zichtbaar gemaakt. De witte balk in de figuur geeft $500 \mathrm{~m}$ weer. 


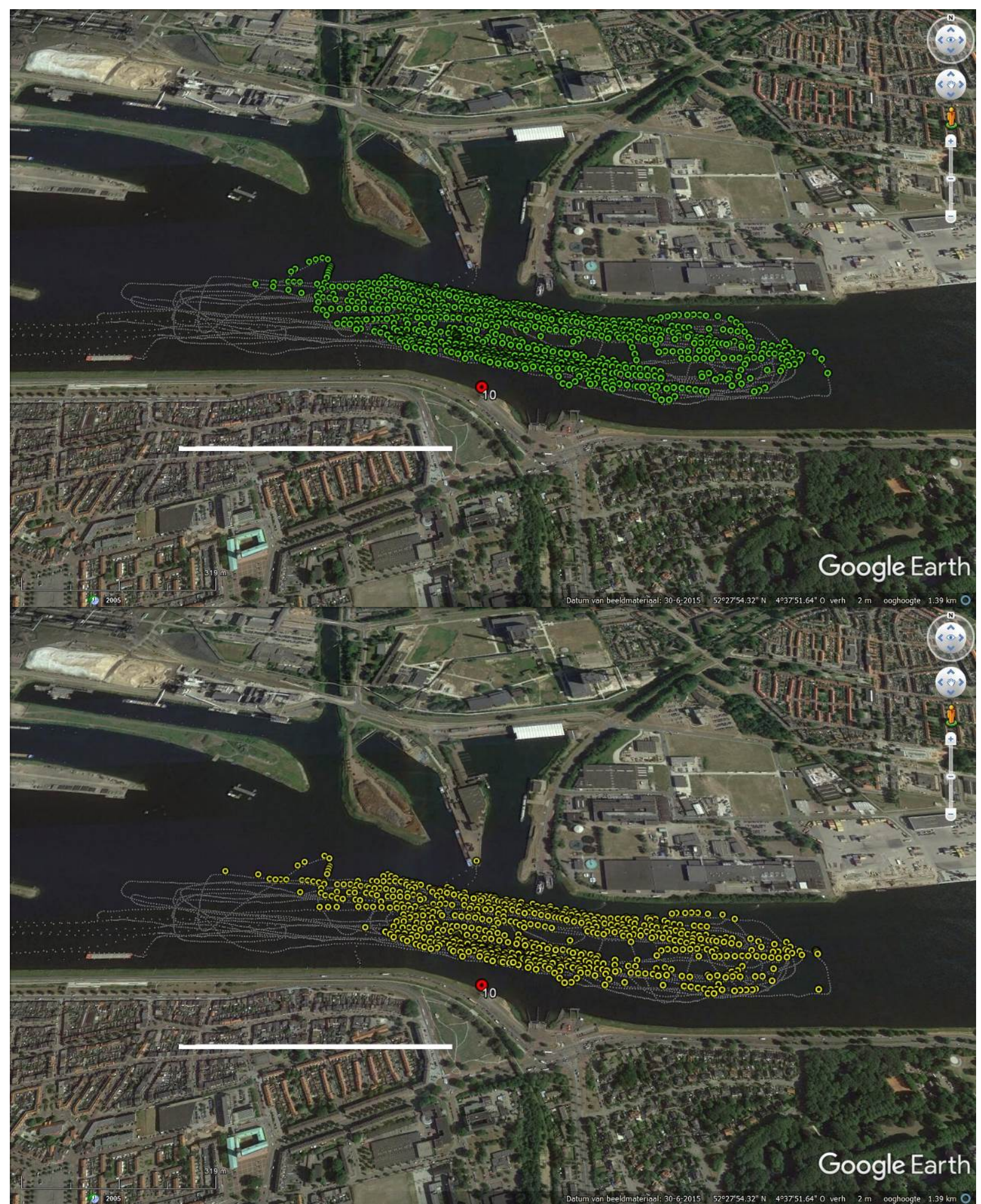

Figuur 4.6 vervolg. Detecties bij ontvanger 10 (rode punt) van de ondiepe zender (groen, boven) en de diepe zender (geel, onder) tijdens beide vaardagen. De vaarbewegingen zijn met een witte lijn zichtbaar gemaakt. De witte balk in de figuur geeft $500 \mathrm{~m}$ weer. 


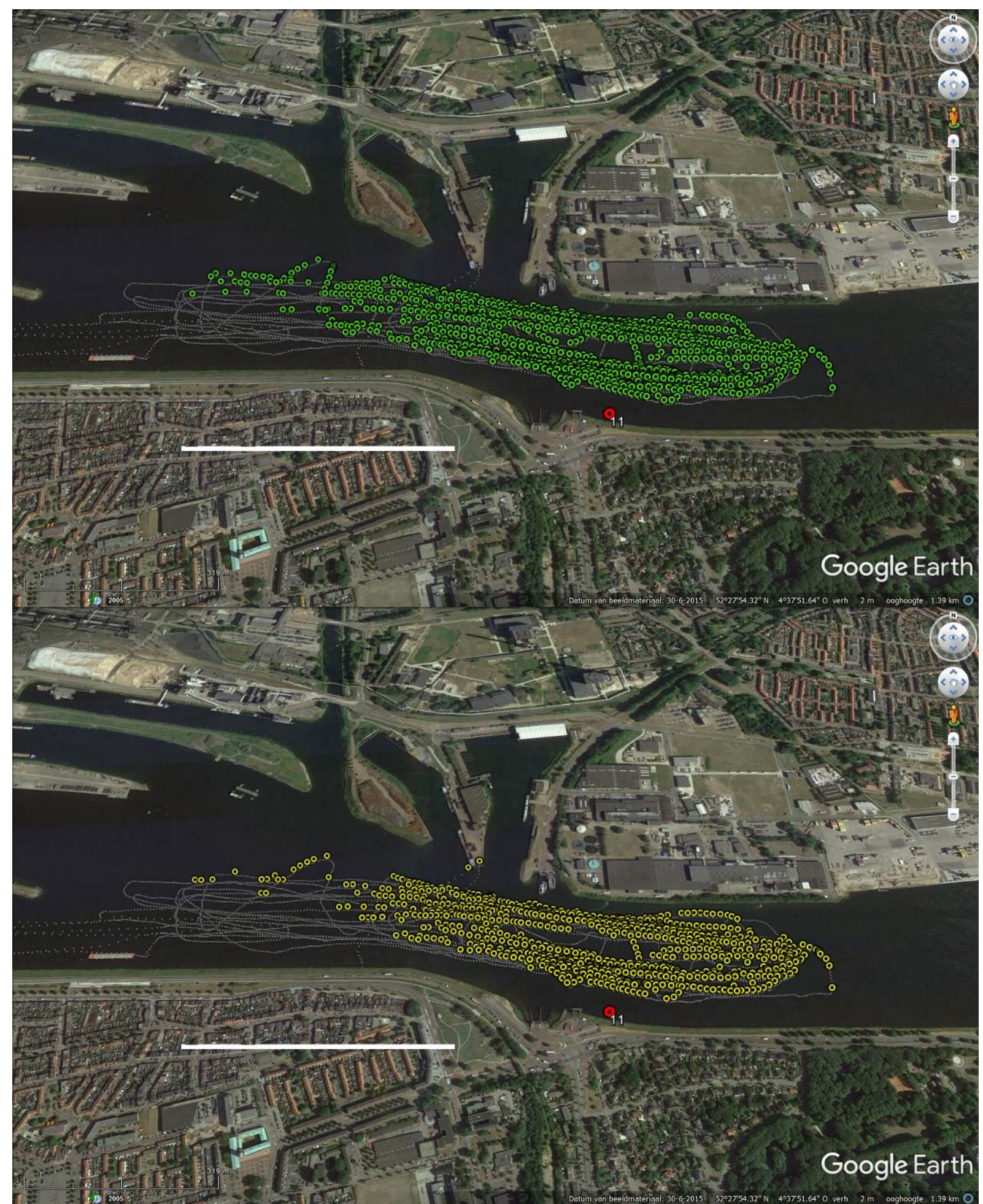

Figuur 4.6 vervolg. Detecties bij ontvanger 11 (rode punt) van de ondiepe zender (groen, boven) en de diepe zender (geel, onder) tijdens beide vaardagen. De vaarbewegingen zijn met een witte lijn zichtbaar gemaakt. De witte balk in de figuur geeft $500 \mathrm{~m}$ weer. 


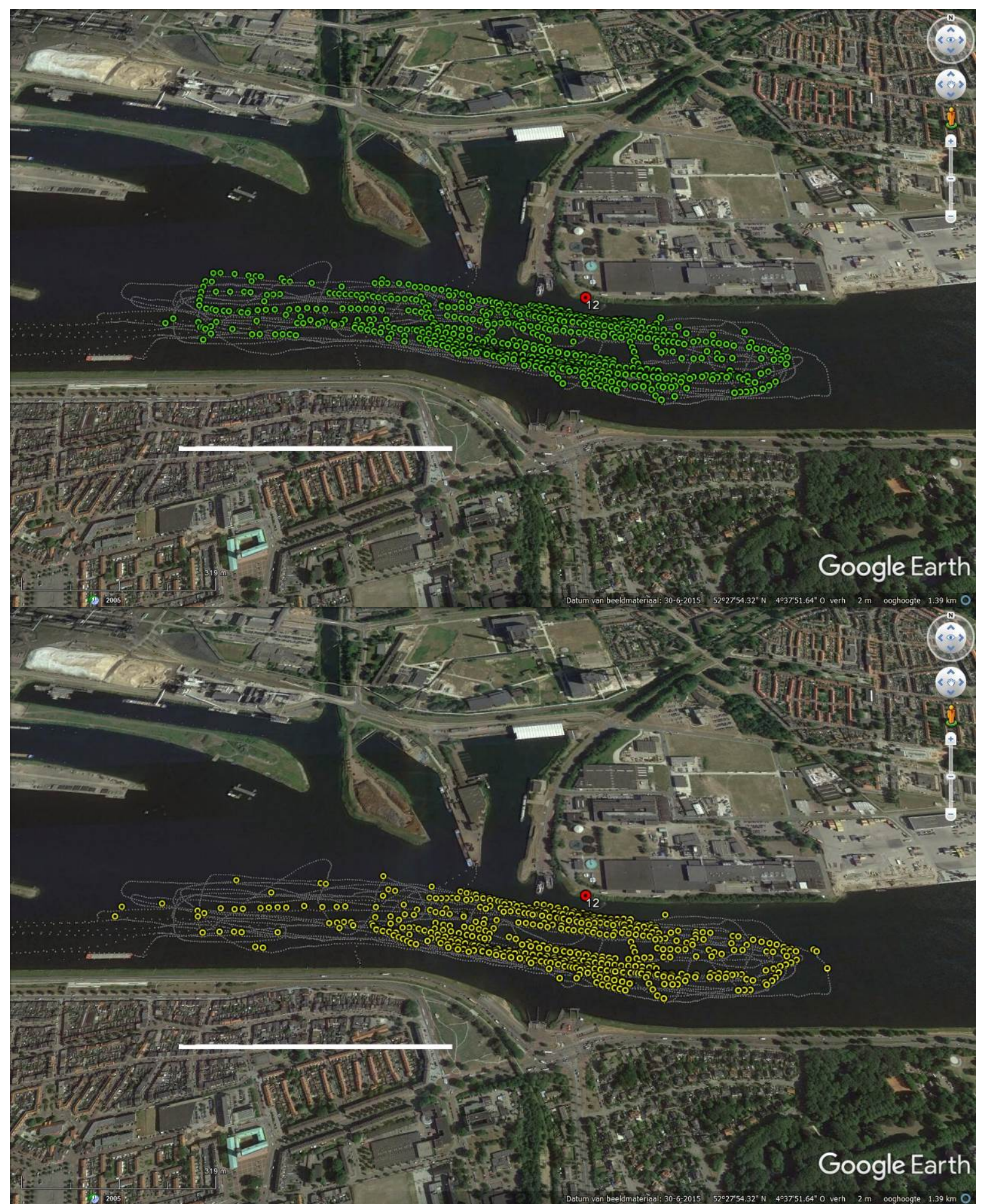

Figuur 4.6 vervolg. Detecties bij ontvanger 12 (rode punt) van de ondiepe zender (groen, boven) en de diepe zender (geel, onder) tijdens beide vaardagen. De vaarbewegingen zijn met een witte lijn zichtbaar gemaakt. De witte balk in de figuur geeft $500 \mathrm{~m}$ weer. 


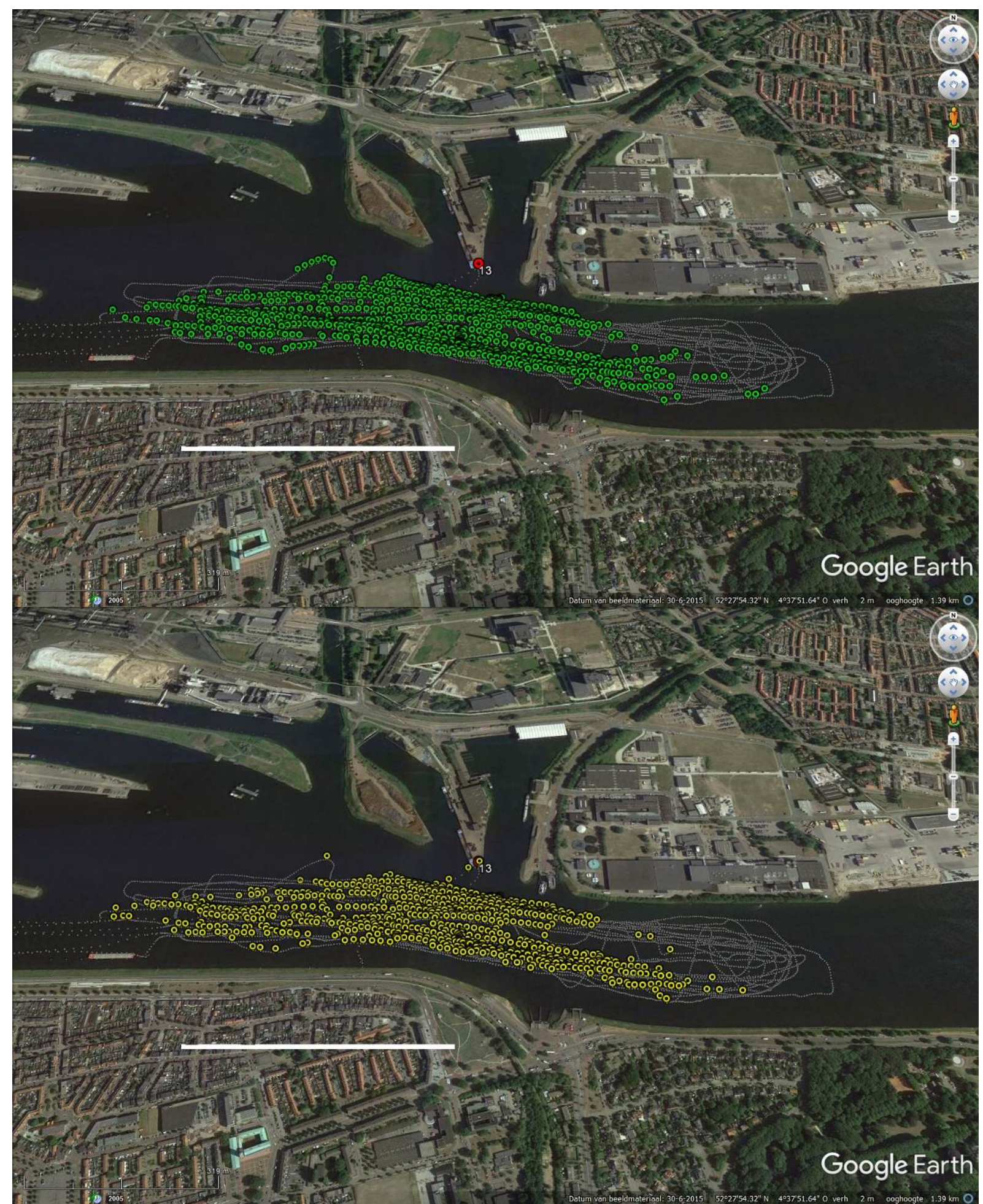

Figuur 4.6 vervolg. Detecties bij ontvanger 13 (rode punt) van de ondiepe zender (groen, boven) en de diepe zender (geel, onder) tijdens beide vaardagen. De vaarbewegingen zijn met een witte lijn zichtbaar gemaakt. De witte balk in de figuur geeft $500 \mathrm{~m}$ weer. 


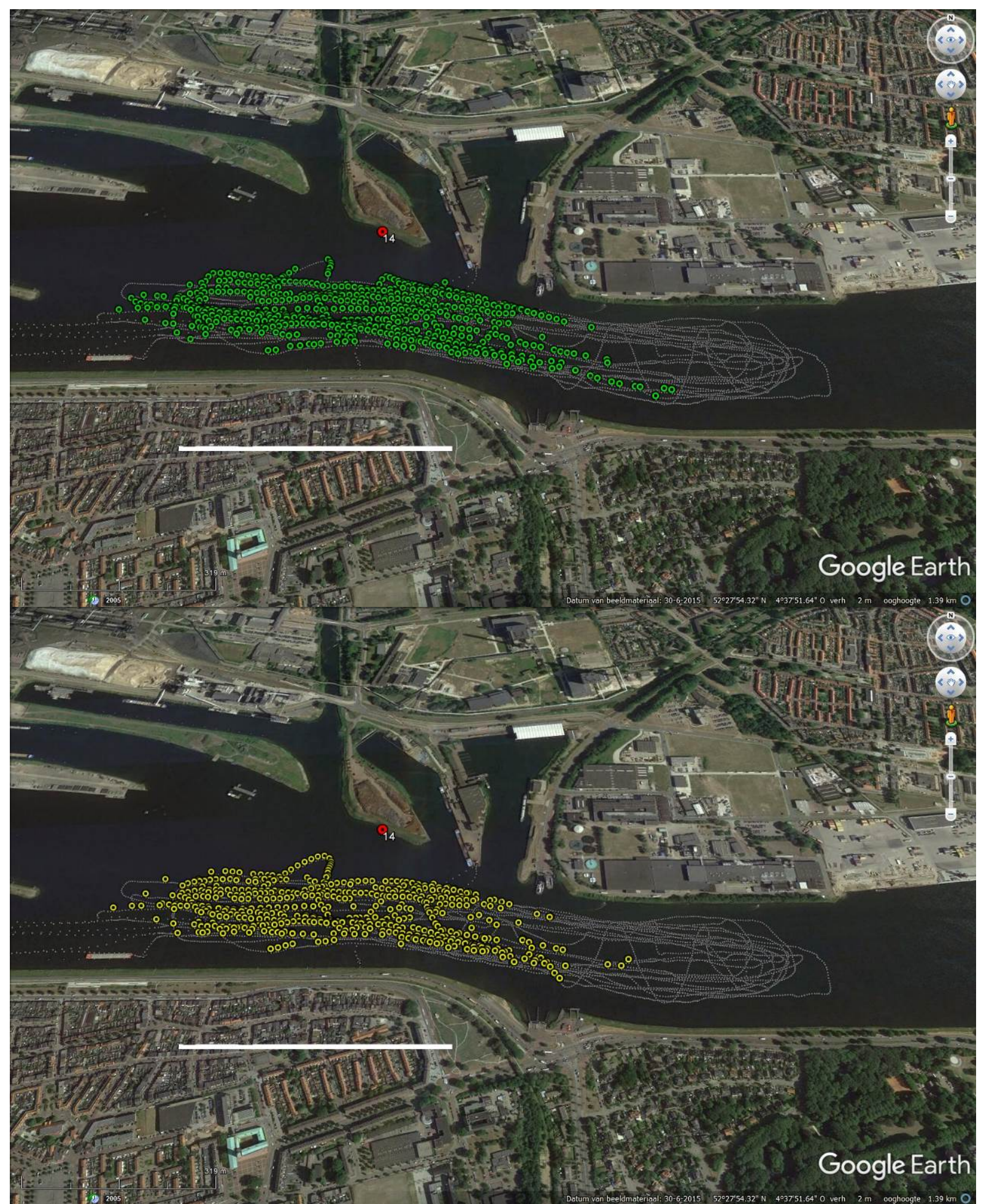

Figuur 4.6 vervolg. Detecties bij ontvanger 14 (rode punt) van de ondiepe zender (groen, boven) en de diepe zender (geel, onder) tijdens beide vaardagen. De vaarbewegingen zijn met een witte lijn zichtbaar gemaakt. De witte balk in de figuur geeft $500 \mathrm{~m}$ weer. 


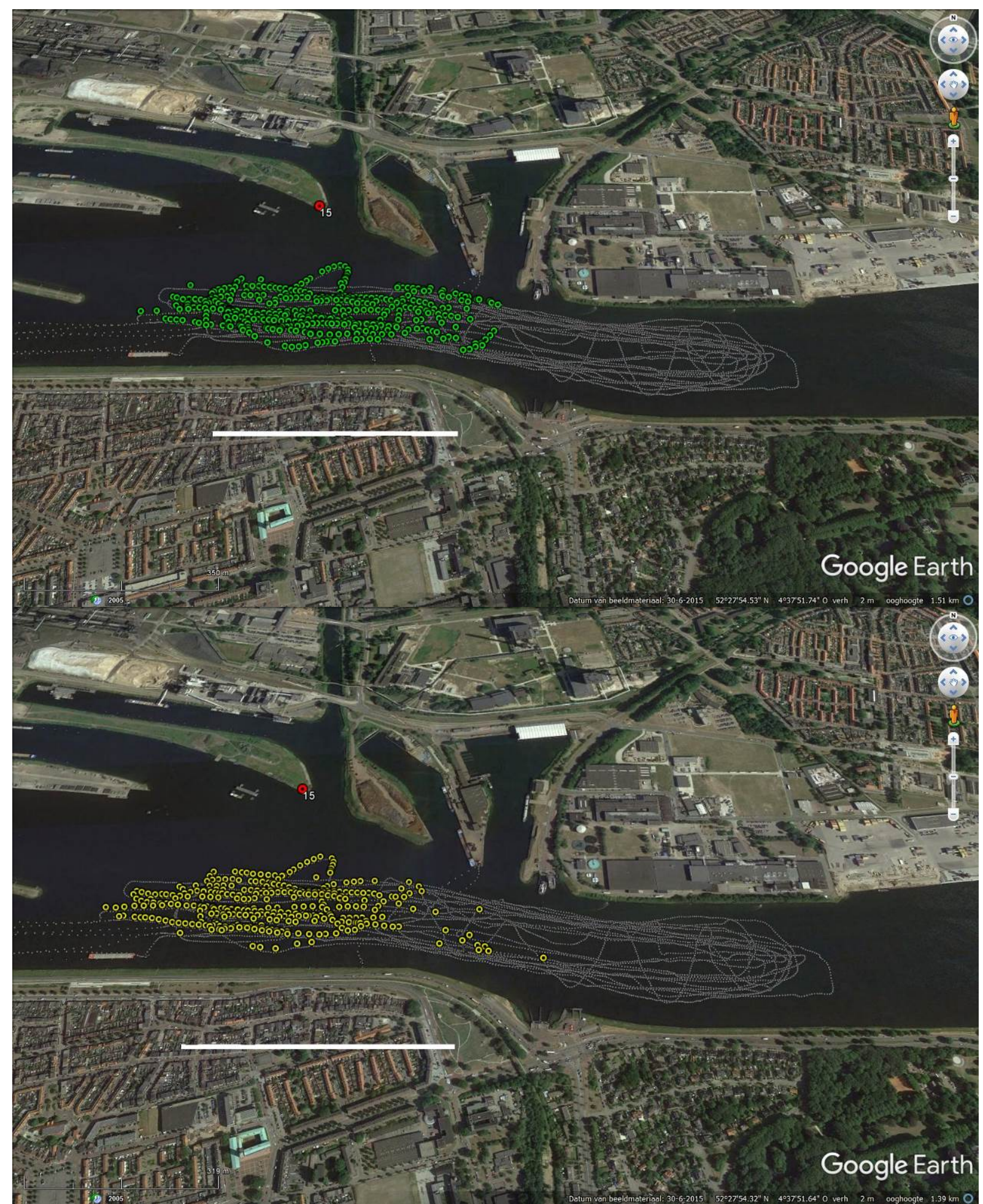

Figuur 4.6 vervolg. Detecties bij ontvanger 15 (rode punt) van de ondiepe zender (groen, boven) en de diepe zender (geel, onder) tijdens beide vaardagen. De vaarbewegingen zijn met een witte lijn zichtbaar gemaakt. De witte balk in de figuur geeft $500 \mathrm{~m}$ weer. 


\subsubsection{Scheepvart tijdens kort lopende proef}

Tijdens de vaarroute van de kort lopende proef is gevaren met de zenders bevestigd aan de booit en zijn ten tijde van het varen voorbijvarende schepen geregistreerd. Omdat niet is vast te stellen op welk tijdstip een schip op welke positie was, is het niet mogelijk uit de gegevens te halen of grote schepen een duidelijke fysieke barrière vormen tussen de zender en de ontvangers. Daarvoor zijn de schepen veelal te klein om een zekere misdetectie die wordt veroorzaakt door de schepen waar te nemen. Indien dit plaats zou vinden, was deze belemmering van beperkte duur. Bij grote schepen was een eventuele misdetectie beter vast te stellen, zij het indicatief, als gevolg van het passeren. Er zijn drie situaties bekeken met grote passerende schepen $>100 \mathrm{~m}$ 


\section{Situatie 1 op dag 1.}

Zelfstandig varend schip passerend (ca. 180m lang) aan de noordkant t.o.v. het onderzoeksschip richting zee om 9.43 uur (links) en een zelfstandig schip (ca. 190m lang) passerend op 12.26 uur aan de noordkant t.o.v. het onderzoeksschip richting zee (rechts). De stippellijn is het gevaren traject met beide zenders. In het rood zijn - ter illustratie - enkele mogelijke blokkering van het signaal weergegeven. Hierbij geldt dat er wel een signaal was verwacht (op basis van vergelijkbare situatie zonder schip), maar niet werd geregistreerd. Het lijkt erop dat het signaal werd geblokkeerd. In de eerste situatie zijn twee zelfstandig varende, grote, schepen gevolgd. Deze schepen voeren ten noorden van het onderzoeksschip. Door de ontvangers aan de zuidoever, welke het dichtstbij de zenders waren, werden de zenders, zowel diep als ondiep, gedetecteerd tijdens het voorbijvaren van het schip tussen het onderzoeksschip en de zuidoever (links in de figuur ontvanger 10 en 11). Bij de ontvangers aan de noordoever zijn 'veel' detecties bij ontvanger 12 maar 'minder' bij ontvanger 13. Bij alle ontvangers is een 'gat' zichtbaar in de reeks van detecties. Er is geen overlap in dit 'gat' bij ontvangers 10, 11 en 12. Dit is wel het geval bij ontvangers 12 en 13 waarbij er gelijktijdig geen detecties zijn geweest. De afwezigheid van detecties bij ontvangers 7-9 en 14-15 heeft hoogstwaarschijnlijk te maken met een 'dode hoek' in het signaal. Bij het andere schip was geen blokkering van het signaal zichtbaar bij de ontvangers waarbij verwacht werd dat ze het signaal oppikken (7-11). Indien het signaal niet meer wordt opgepikt in de tijd, dan is dit het gevolg van een 'dode hoek'. Bij de ontvangers 12 en 13 zijn er wel enkele misdetecties, blokkades, waarneembaar die mogelijk het gevolg zijn van het passerend schip.
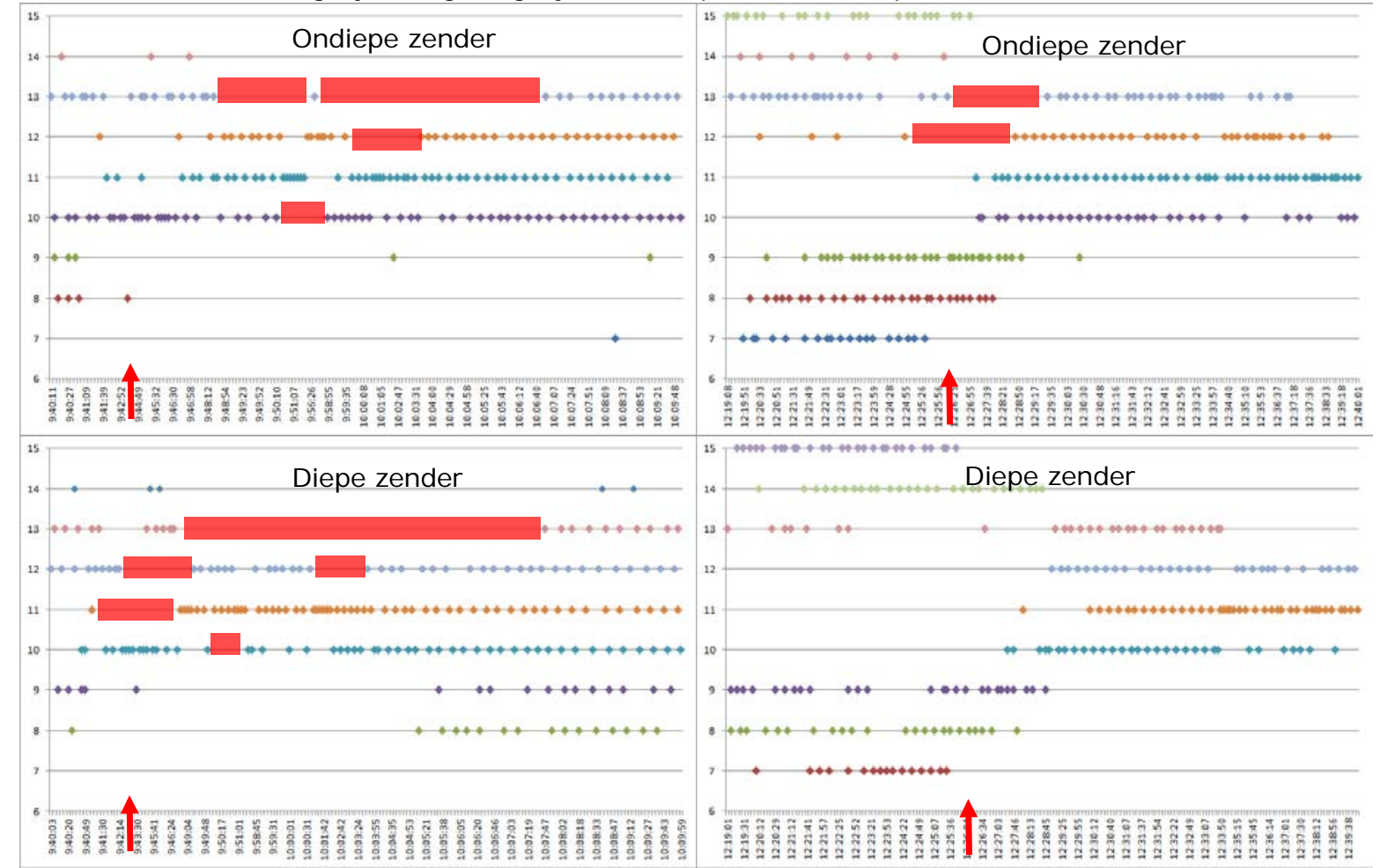

Fig.S1. detecties (symbolen in grafiek met op de X-as tijd (HH:mm:ss) en op de Y-as ontvangers (\#). FotoS1 links correspondeert met de linkers grafieken. Idem voor de FotoS1 rechts geldt dat deze correspondeerd met de rechter grafieken.

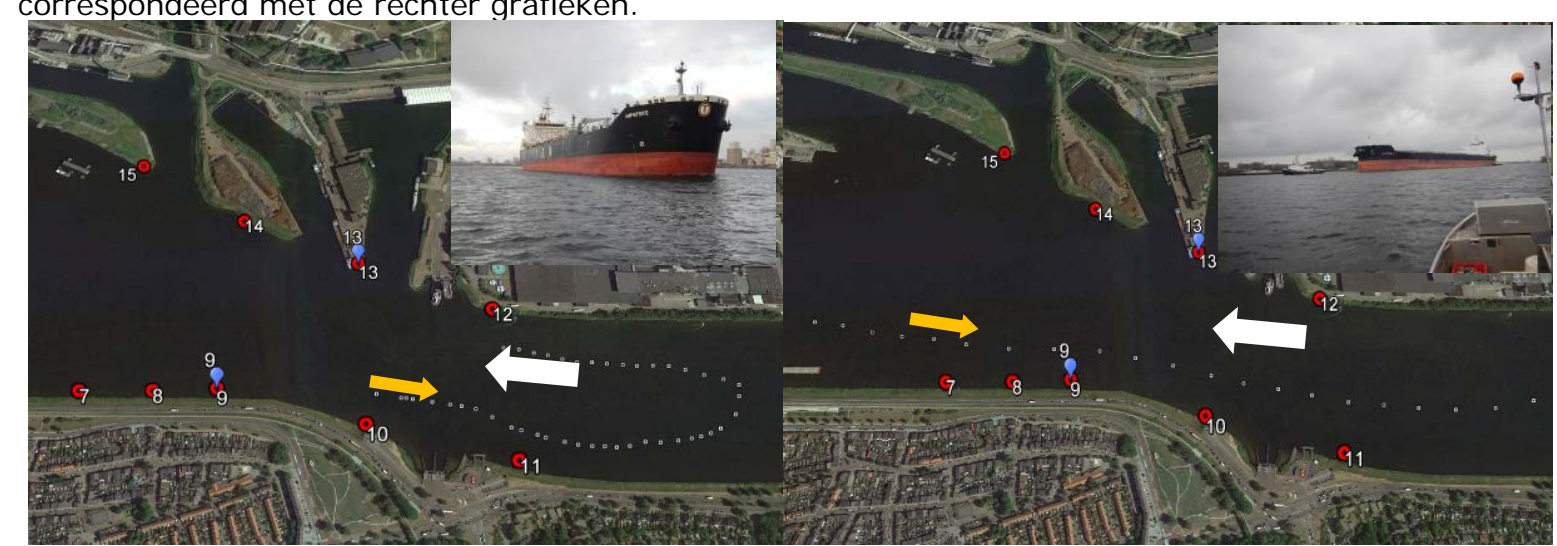

FotoS1. Twee schepen ten tijde van de proef. De witte stippen geven waypoints aan van het onderzoeksschip 


\section{Situatie 2 op dag 2.}

Zelfstandig varend schip passerend om 10.31 (ca. 100m lang) aan de zuidkant (links) en schepen passerend (sleepboot + grote boot) aan de noordkant richting zee om 11.35 uur (ca. 200m lang) en enkel schip om 11.55 uur (rechts). De stippellijn is het gevaren traject met beide zenders. In het rood zijn indicatief enkele mogelijke blokkering van het signaal weergegeven.

In de tweede situatie is een zelfstandig varend, middelgroot, schip gevolgd waarbij er misdetecties, blokkering van het signaal, zijn bij ontvanger 13. Bij ontvangers 8, 9 en 12 zijn onregelmatige detecties waarneembaar. De overige ontvangers vallen deels in een 'dode hoek'. Bij het tweede schip wat werd voortgetrokken is, een mogelijke blokkering van het signaal te zien bij ontvangers 12 en 13 . Bij het omkeren van het onderzoeksschip waarbij het grote schip nogmaals werd gepasseerd is er kortdurig een onregelmatig signaal zichtbaar bij de ontvangers.

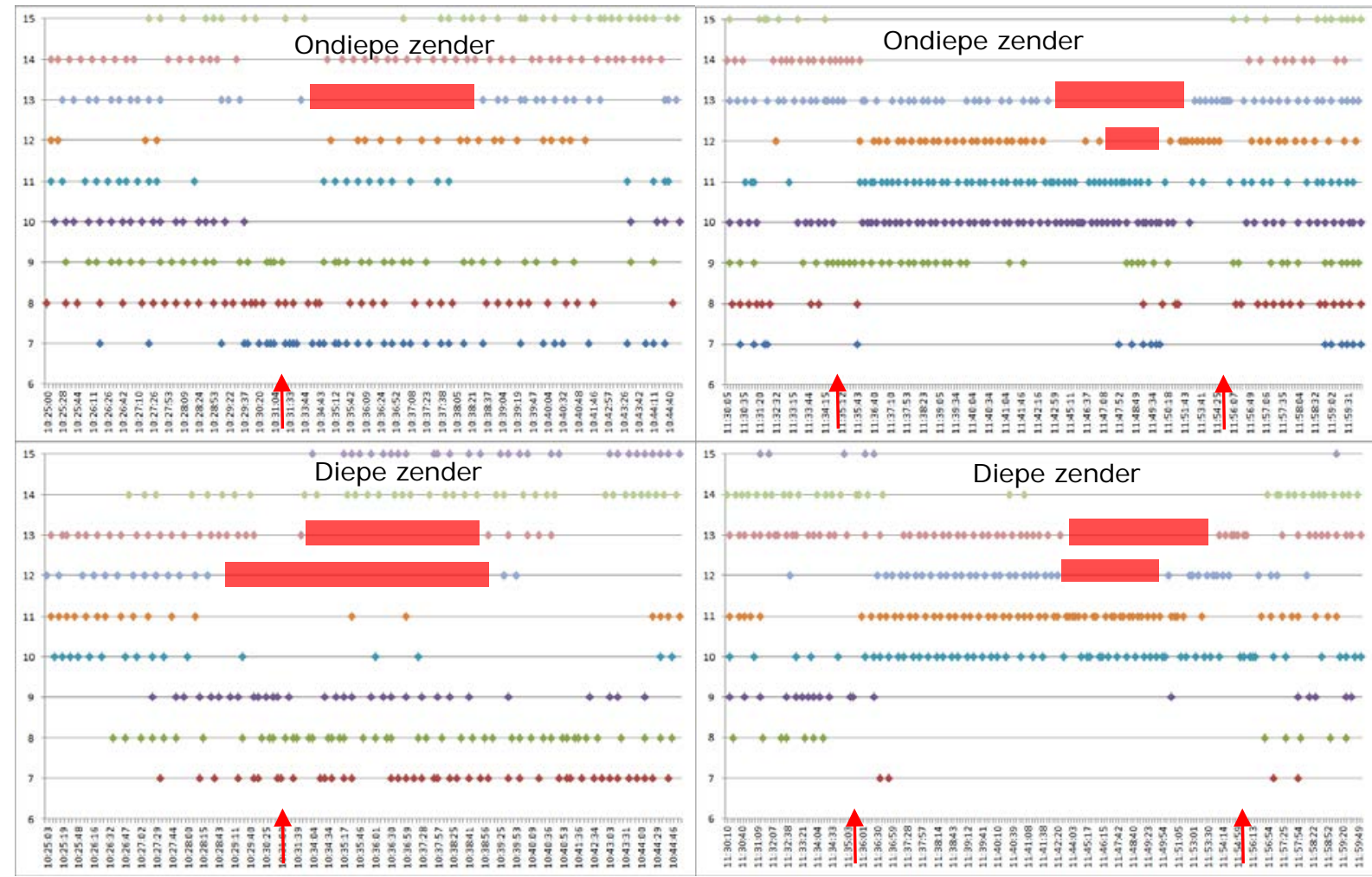

Fig.S2. detecties (symbolen in grafiek met op de X-as tijd (HH:mm:ss) en op de Y-as ontvangers (\#). FotoS2 links correspondeert met de linkers grafieken. Idem voor de FotoS2 rechts geldt dat deze correspondeerd met de rechter grafieken.

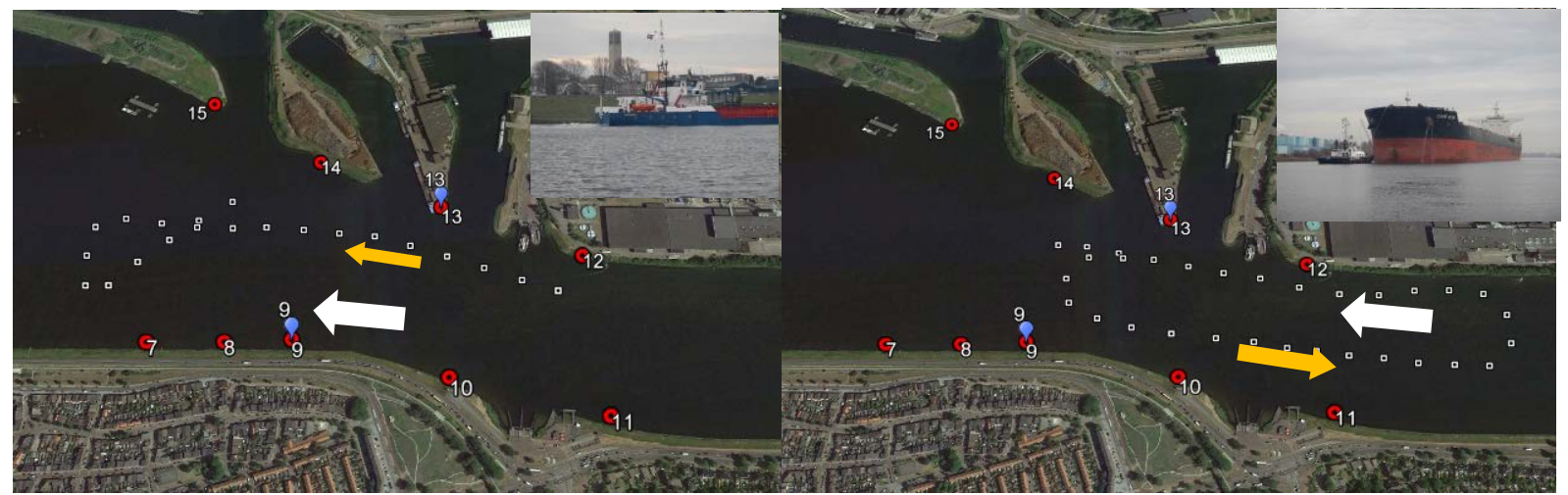

FotoS2. Twee schepen ten tijde van de proef. De witte stippen geven waypoints aan van het onderzoeksschip 


\section{Situatie 3 dag 1 en dag 2}

Op testdag 1. Twee grote schepen gelijktijdig passerend aan de noordzijde t.o.v. de zenders om 11.14 en 11.16 uur. Tweede situatie waarbij drie grote schepen passerend aan de noordzijde op 13.04, 13.07, 13.09 uur en een schip passerend aan de zuidzijde op 13.31 uur op testdag 2 (rechts). In het rood zijn indicatief enkele mogelijke blokkering van het signaal weergegeven. In de linker situatie is een volledige blokkering van het signaal op alle ontvangers zichtbaar, ook als het schip niet tussen zender en ontvanger door vaart. Deze duurt ongeveer 5 minuten lang voor de ondiepe zender, maar korter voor de diepe zender. In de rechter situatie is dit ook zichtbaar waar het signaal kort, circa 1 minuut volledig wordt geblokkeerd.
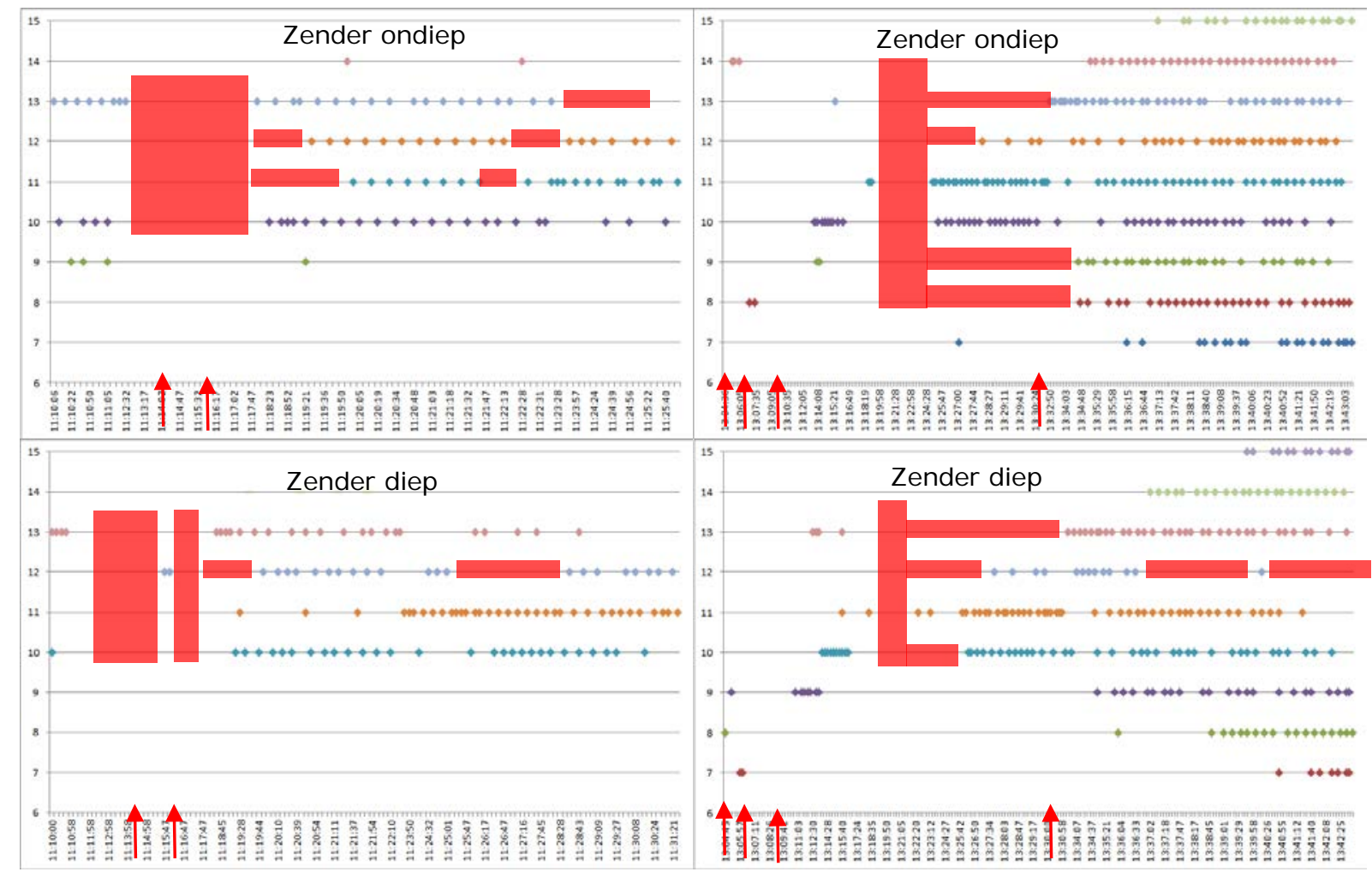

Fig.S3. detecties (symbolen in grafiek met op de X-as tijd ( $\mathrm{HH}: \mathrm{mm}$ :ss) en op de Y-as ontvangers (\#). FotoS3 links correspondeert met de linkers grafieken. Idem voor de FotoS3 rechts geldt dat deze correspondeerd met de rechter grafieken.

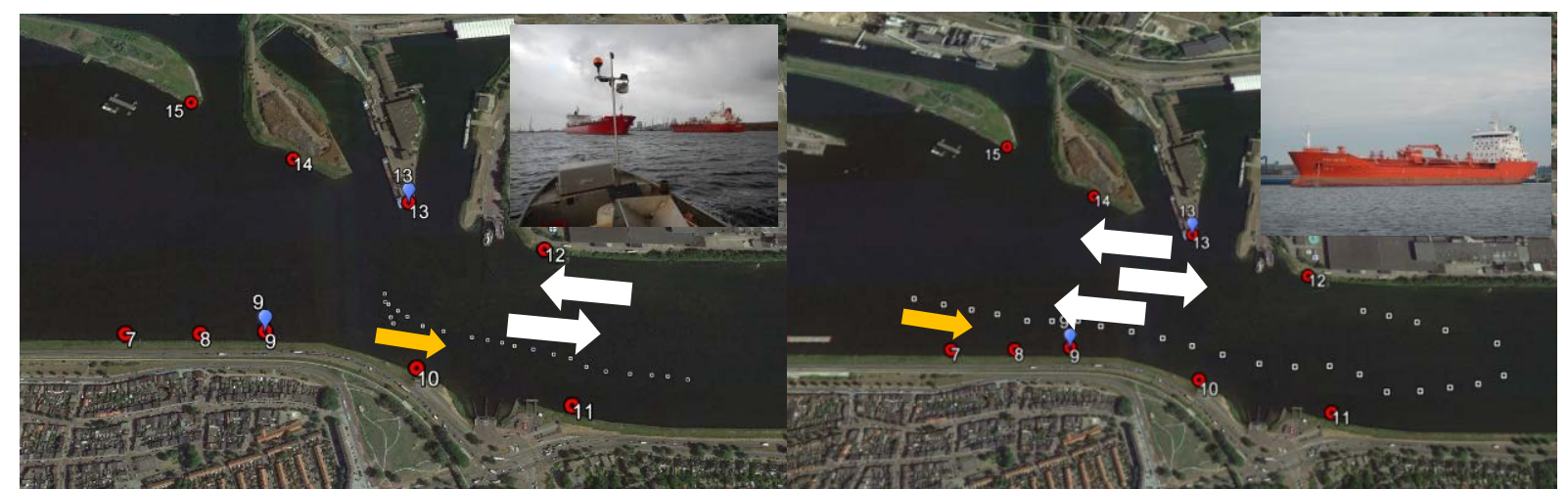

FotoS3. Twee schepen ten tijde van de proef. De witte stippen geven waypoints aan van het onderzoeksschip 


\section{Conclusie, discussie en aanbevelingen}

\subsection{Ontvangstverschil ontvanger 1 en 2 met zender $A$ en $B$}

Met de leverancier van de apparatuur (VEMCO) is de ontvangst van de signalen op ontvangers 1 en 2 nauwkeuriger geanalyseerd. Uitgaande van een 30 seconden rustpauze tussen twee puls-treinen, worden door de twee zenders op die locatie circa 5300 puls-treinen per dag uitgezonden. Ontvanger 2 liet circa 5000 SYNC's zien per dag. In tegenstelling tot ontvanger 1, die 7000-8000 SYNC's liet zien. Dit is hoger dan wat op basis van de werking van de zenders verwacht kon worden. Voor het hogere aantal signalen zijn verschillende redenen aan te wijzen:

- Verstorende geluiden maakten een valide SYNC interval, waardoor de ontvanger begon met registreren van een mogelijke (foutieve) puls trein;

- Als de ontvangst laag is en minder dan acht geluiden van een zender bereiken de ontvanger, dan zouden twee tussenliggende pings een aanvullende SYNC periode kunnen starten;

- Door reflecties (vb. via damwanden; Figuur 5.1) van de uitgezonden pulsen van een zender die de ontvanger bereiken (dus meer dan acht pulsen uitgezonden door de zender bereiken de ontvanger), worden meerdere SYNC's gestart. In het algoritme van de ontvanger wordt na elke detectie een tijdsperiode ingesteld van 260ms waarin een ander geluid niet geregistreerd kan worden om foutieve detecties via weerkaatsing tegen te gaan. Echter als het geluid wordt weerkaatst na dit tijdsinterval, is een extra signaaldetectie via weerkaatsing mogelijk.

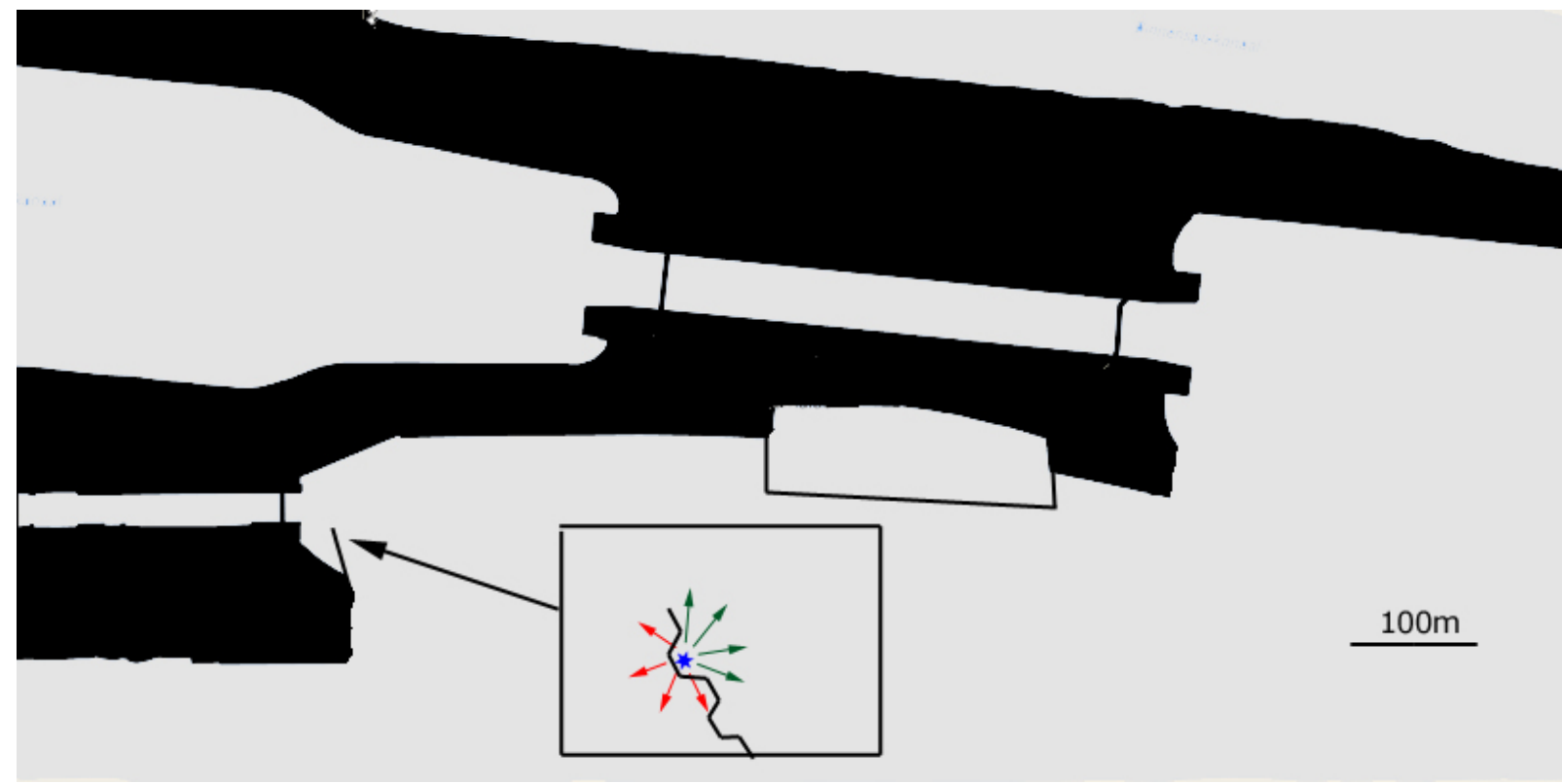

Figuur 5.1 Plaatsing zender A nabij een damwand. De rode pijlen geven een signaal rechtstreeks tegen de damwand weer die mogelijk weerkaatst kan worden. Anderzijds kan een signaal (groene pijl) ook weerkaatst worden door een damwand aan de overzijde van het kanaal, waar de ontvangers geplaatst zijn.

De ontvanger op locatie 1 had een hoog aantal geweigerde treinpulsen voor wat betreft zender A, welke op basis van enkel de aanwezigheid van twee niet overlappende zenders niet aanwezig zouden moeten zijn. Achtergrondgeluid, reflecties of blokkering van het geluid door de damwand kunnen de oorzaak hiervan zijn, waardoor wel acht geluiden op de juiste intervallen door de ontvanger worden geregistreerd, maar de detecties verworpen worden door de foutendetectie in het algoritme in de ontvanger. Figuur 5.2, waarvoor de gegevens door VEMCO geanalyseerd zijn, laten het tijdverschil zien tussen de eerste twee signalen tussen ontvanger 1 (Figuur 5.2, links) en ontvanger 2 (Figuur 5.2, rechts). Waarbij bij ontvanger 2 het vaste tijdsinterval tussen de eerste twee signalen elke keer gelijk is (wat men zou verwachten), is bij ontvanger 1 de variatie aanzienlijk tussen het interval tussen signaal 1 en 2. Dit betekent dat er verstorende geluiden zijn geweest bij ontvanger 1 die foutieve eerste en/of tweede signalen hebben aangemaakt. Waarschijnlijk heeft de damwand die geplaatst was "haaks" op de 
oever voor de aanleg van de nieuwe zeesluis (locatie zender A) geresulteerd in ongewenste reflecties van geluid, waardoor ontvanger 1 op een minder geschikte locatie staat voor de plaatsing van een ontvanger voor een toekomstig onderzoek.

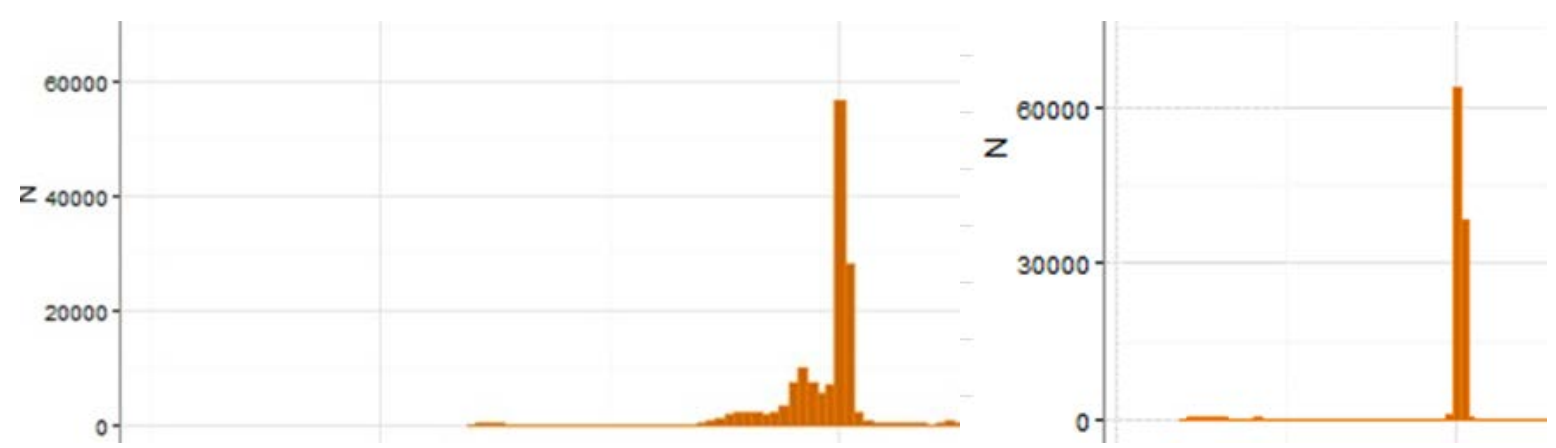

Figuur 5.2 Tijdsinterval tussen eerste twee geluidspulsen voor de ontvangers 1 (links) en 2 (rechts)

\subsection{Ontvangst zender A en B op ontvanger 4}

Opvallend is de duidelijke dip bij ontvanger 4 voor zender A en B. Deze dip is in mindere mate ook te zien bij de ontvangers 1 en 2. De dip is gekoppeld aan een tijdstip van grofweg 06:00-18:00 waarbij het intensieve vaarverkeer van bouwwerkzaamheden een blokkerende werking heeft op het signaal. Een soortgelijke dip met vergelijkbaar tijdspad, is ook, maar veel minder sterk, zichtbaar bij ontvangers van zenders $C$ en D bij de langlopende proef op het kanaal. De dip bij zenders C en D is mogelijk het gevolg van het veerpont verkeer.

\subsection{Detectie range en belemmering scheepvaart}

Over het algemeen wordt het signaal dat V9 zenders uitgeven ontvangen over een afstand tot 400-500m (Melnychuk 2012). Dit is echter sterk afhankelijk van de lokale omstandigheden, zo is in de huidige studie het signaal tot $1 \mathrm{~km}$ ver ontvangen (Figuur 4.5, Tabel 4.1). Ook in oudere typen V2 ontvangers (in deze studie zijn V2RW ontvangers gebruik) werden V9 zenders meer dan $70 \%$ van de signalen over een afstand van minimaal $500 \mathrm{~m}$ ontvangen en in een langzaam stromende rivier werden in meer dan $80 \%$ van de gevallen de signalen rond de 450 m ontvangen (Ammann et al. 2007).

In deze studie is gebleken dat de scheepvaart een belemmering kan opleveren, waarbij het signaal in sommige gevallen een paar minuten verstoord kan worden. In één van de gevallen was dit zo'n 5 minuten. Er zijn verschillende mechanismen waarlangs scheepvaart de propagatie van een signaal kan verstoren: 1) door directe blokkade van het schip als object tussen zender en detectiestation; 2) door turbulentie en bellen in het water als gevolg van schroefwater; 3) door maskering van het signaal van een zender door onderwatergeluid dat wordt gemaakt door het schip. Bij mechanisme 3 kan worden opgemerkt dat het overgrote deel van het scheepgeluid laagfrequent geluid is dat ver beneden de hoge frequentie van $69 \mathrm{kHz}$ liggen die het VEMCO systeem gebruikt. Mechanisme 1 en 2 lijken de belangrijkste redenen voor verstoring op te leveren en de kans op mechanisme 3 is veel kleiner. De tijdsduur waarover directe blokkade van het signaal potentieel plaats vindt kan aan de hand van de lengte, diepgang van het schip en de vaarsnelheid worden bekeken. Voor langduriger verstoring lijkt een turbulentie- bellenspoor een meer voor de hand liggende reden. $\mathrm{Bij}$ een toekomstige studie is het daarom het beste om een dubbele opstelling te hebben waarbij een misdetectie van passerende schieraal wordt voorkomen. Dit wil zeggen dat de ontvangers zo worden opgesteld dat er een overlap is in het bereik, bijvoorbeeld ten noorden en ten zuiden van een kanaal, recht tegenover elkaar. Indien een schieraal zich met 0.5 lichaamslengte ('body length') per seconde verplaatst met een lengte van zo'n $60-100 \mathrm{~cm}$ (van den Thillart et al. 2004, Keeken et al. 2016), zwemmen ze 0.3-0.5 m/s. In de rivieren is een gemiddelde van $0.62 \mathrm{~m} / \mathrm{s}$ waargenomen, dus zwemsnelheid inclusief stroming van het water (Verbiest et al. 2012). Indien het signaal voor 5 minuten verstoord wordt kan een schieraal die $0.62 \mathrm{~m} / \mathrm{s}$ zwemt zich $186 \mathrm{~m}$ verplaatsen. Hierbij moet men in werkelijkheid rekening houden dat een schieraal in het Noordzeekanaal niet met de stroming mee zal zwemmen zoals dat op de rivieren wel het geval is. Op het Noordzeekanaal zal een schieraal zich dus langzamer verplaatsen. Ook als de schieraal zich met $0.62 \mathrm{~m} / \mathrm{s}$ verplaatst, zal 
de 186 meter alsnog ruim binnen de detectie range van een V9 zender vallen. Met een zwemsnelheid van $1 \mathrm{~m} / \mathrm{s}$ zal de schieraal binnen 5 minuten zich 300 meter verplaatsen en ook dat valt binnen de detectie range van een V9 zender. De maximum waargenomen range binnen dit onderzoek was tot wel een 970 meter (Tabel 4.1), waarbij uitgegaan is van de straal van de detectierange en in werkelijkheid de detectie dubbel zo groot is. Daar komt bij dat een zender met een delay (tijd tussen twee opeenvolgende geluidspulstreinen door een zender) van $30 \mathrm{sec}$ dan inmiddels zo'n 10 signalen heeft afgegeven. Met een dubbele opstelling zal het signaal, ondanks een potentiele langdurige blokkering, alsnog meerdere malen worden opgevangen. Bij een schutsluis, spuisluis of gemaal zal deze kans nog groter zijn, omdat een schieraal zal moeten wachten of zoekgedrag vertoont om een migratie mogelijkheid te vinden.

In de vorige alinea is uitgegaan van een bepaalde zwemsnelheid en de kans dat het signaal wordt geblokkeerd door een groot schip, waardoor enkele minuten geen signaal kan worden opgevangen. In de volgende beschouwing wordt de kans berekend op het missen van een gezenderde aal afhankelijk van de detectierange. In Tabel 5.1 en 5.2 is een overzicht weergegeven van een scenario met een V9 zender met een delay van $30 \mathrm{sec}$. Een zender met een delay van $30 \mathrm{sec}$ heeft een batterij duur van circa 150 dagen (ruim 5 maanden), welke voor een toekomstig project de te overbruggen periode weergeeft. De zender geeft om de $30 \mathrm{sec}$ een signaal af dat ontvangen wordt door ontvangers die geplaatst zijn binnen enkele honderden meters. Op basis van de huidige studie blijkt het signaal te reiken over enkele honderden meters (Figuur 4.5 en 4.6). Indien uitgegaan wordt van een detectie range van 400-500 meter (detectierange in straal) betekent dat het bereik van de zender 800-1000 meter beslaat (detectierange in diameter). Indien een schieraal met een zwemsnelheid van 0.1-0.3 m/s zwemt, dan is het aantal signalen wat wordt gegeven binnen de afstand waarover deze gevolgd kan worden door een ontvanger zo'n 44 - 167 signalen $^{2}$ (Tabel 5.1, groene vlak). Indien de misdetectiekans van een ontvanger geschat wordt op $40 \%$, zoals dit bijvoorbeeld bij de lang lopende proef zichtbaar was bij ontvanger 2 en 3 (Figuur 4.1 en 4.2), dan is de kans $<0.00 \%$ op een misdetectie (Tabel 5.2). Ook als er gerekend wordt met een misdetectie kans van $60 \%$ is de kan $<0.00 \%$ dat er een gezenderde schieraal wordt gemist.

In Tabel 5.2 is het aantal signalen afgezet tegen een bepaalde misdetectie. In een uiterste geval waarbij slechts drie signalen (Tabel 5.1 linksonderste cel) worden afgegeven en er gerekend wordt met een misdetectie kans van $60 \%$ (tabel 5.2), dan is de kans op een misdetectie $0.6^{3}$, ofwel $21.60 \%$ (Tabel 5.2). $\mathrm{Er}$ is in dat uiterste geval $21.60 \%$ kans dat er ook daadwerkelijk een misdetectie van een gezenderde schieraal is. Ter illustratie; het betreft hier het geval waarbij een schieraal $1 \mathrm{~m} / \mathrm{s}$ zwemt, dat is snel, en er is gerekend met een detectie range van $100 \mathrm{~m}$ met een delay van $30 \mathrm{sec}$. Dit scenario lijkt in de praktijk onwaarschijnlijk gezien de hoge zwemsnelheid en het feit dat een V9 zender een groter bereik heeft van 400-500m (straal), waarbij de huidige studie laat zien dat de range kan oplopen tot $1 \mathrm{~km}$.

\footnotetext{
${ }^{2}$ Dit is een minimum scenario omdat het werkelijke bereik $800-1000$ meter is indien men uitgaat van de diameter in bereik.
} 
Tabel 5.1 Overzicht van het aantal signalen met een zender in een aal indien de detectie range ( $\mathrm{m}$, rijen) gelijk is aan 100-1000m onder verschillende zwemsnelheden ( $\mathrm{m} / \mathrm{s}$, kolommen). Er is uitgegaan van een zender die om de 30 seconden een signaal afgeeft.

\begin{tabular}{|c|c|c|c|c|c|c|c|c|c|c|c|}
\hline & \multicolumn{10}{|c|}{ detectie range $(\mathrm{m})$} \\
\hline & & 100 & 200 & 300 & 400 & 500 & 600 & 700 & 800 & 900 & 1000 \\
\hline \multirow{10}{*}{ 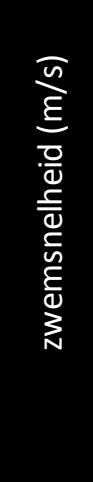 } & 0.1 & 33 & 67 & 100 & 133 & 167 & 200 & 233 & 267 & 300 & 333 \\
\hline & 0.2 & 17 & 33 & 50 & 67 & 83 & 100 & 117 & 133 & 150 & 167 \\
\hline & 0.3 & 11 & 22 & 33 & 44 & 56 & 67 & 78 & 89 & 100 & 111 \\
\hline & 0.4 & 8 & 17 & 25 & 33 & 42 & 50 & 58 & 67 & 75 & 83 \\
\hline & 0.5 & 7 & 13 & 20 & 27 & 33 & 40 & 47 & 53 & 60 & 67 \\
\hline & 0.6 & 6 & 11 & 17 & 22 & 28 & 33 & 39 & 44 & 50 & 56 \\
\hline & 0.7 & 5 & 10 & 14 & 19 & 24 & 29 & 33 & 38 & 43 & 48 \\
\hline & 0.8 & 4 & 8 & 13 & 17 & 21 & 25 & 29 & 33 & 38 & 42 \\
\hline & 0.9 & 4 & 7 & 11 & 15 & 19 & 22 & 26 & 30 & 33 & 37 \\
\hline & 1 & 3 & 7 & 10 & 13 & 17 & 20 & 23 & 27 & 30 & 33 \\
\hline
\end{tabular}

Tabel 5.2 Overzicht van het aantal 'signalen' (horizontaal) en de kans op een misdetectie (\%) onder verschillende misdetectie kansen (verticaal)

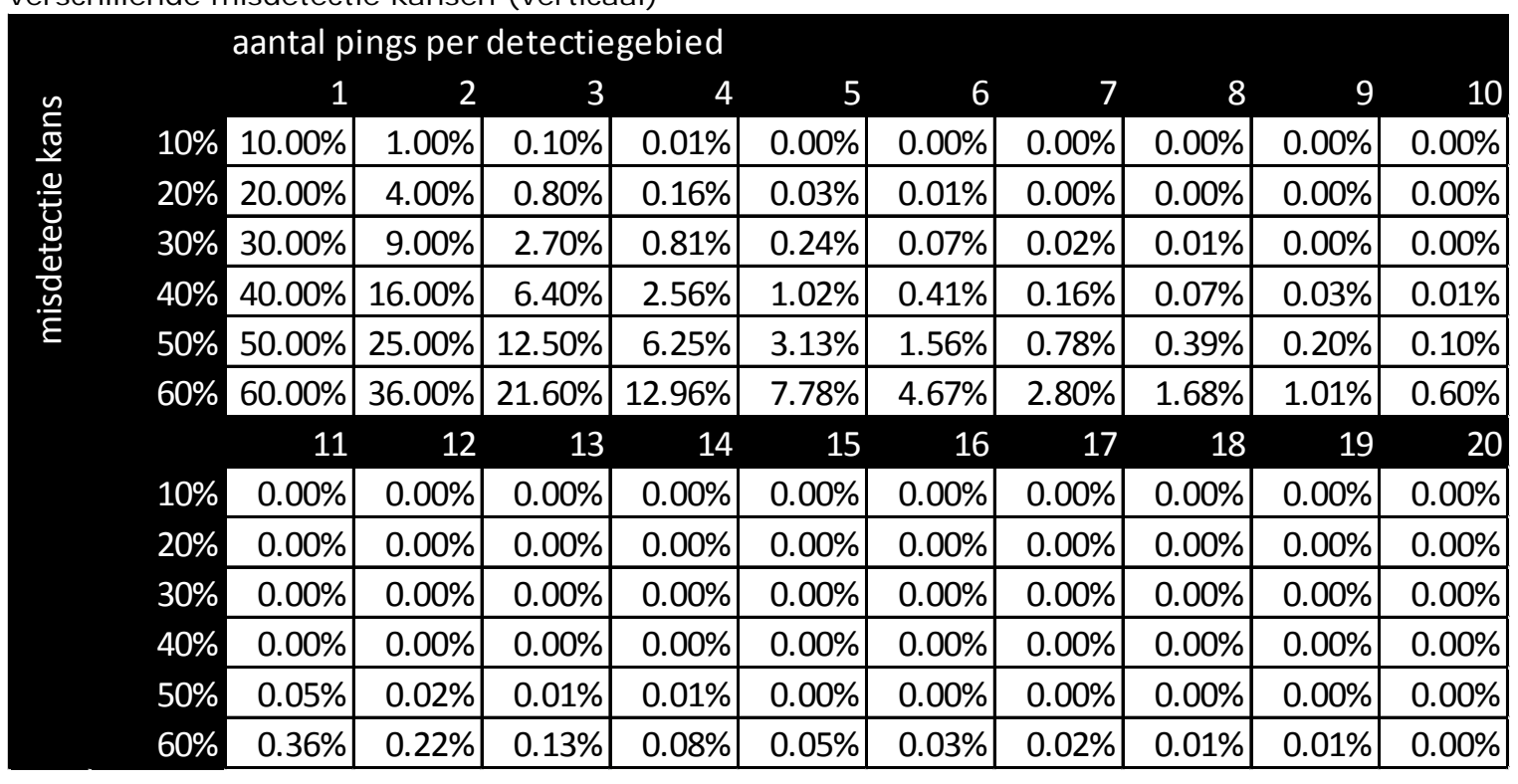

\subsection{Conclusie} Is VEMCO techniek geschikt om toe te passen op het Noordzeekanaal voor de uittrek van
schieraal? Zo ja, met welke factoren moet rekening gehouden worden?

$\mathrm{Ja}$, de techniek is te gebruiken op het Noordzeekanaal met als doel de uittrek van schieraal vast te stellen. Het bereik van de V9 VEMCO zenders op het Noordzeekanaal is tot wel $1 \mathrm{~km}$ ver waargenomen, zodat er maar een minimale kans is voor een gezenderde schieraal om ongezien een detectiestation te passeren, rekening houdend met een misdetectiekans per uitgezonden signaal door scheepvaart of andere invloeden. Een eventuele blokkering van het signaal door zeer grote schepen $(>100 \mathrm{~m})$ is aanwezig, maar rekening houdende met de zwemsnelheid en het bereik van de zenders zal een gezenderde aal niet gemist worden, hooguit een deel van de uitgezonden signalen terwijl de schieraal binnen het bereik van een detectiestation aanwezig is.

De invloed van de intensieve scheepvaart op de techniek was zichtbaar bij de langlopende proef, met een duidelijk dip in de detecties overdag bij sommige ontvangers. Echter, op deze locatie werd ten tijde van de proef intensief gevaren met werkboten die aan de nieuwe sluis aan het bouwen waren. Het betreft daarom naar alle waarschijnlijkheid een worst case scenario. Het signaal werd bij andere ontvangers, 
waar 'normaal' scheepsverkeer passeerde, goed ontvangen met rond de $80 \%$ van de maximaal uitgezonden signalen (bv. zender B met ontvanger 1 ). Daarnaast zal een zwemmende vis ook bepaald zwemgedrag kunnen vertonen als zoek-, terugkeergedrag etc, wat de kans op ongedetecteerde passage nog verder verkleint. In deze proef is gewerkt met een vaste opstelling met een vaste zender op één locatie, terwijl een bewegende vis met zender voor een detectie gunstiger is.

Damwanden lijken het signaal mogelijk te verstoren door weerkaatsing van het signaal (zender $A$, ontvanger 1 en 2 in vergelijking met zender $B$, ontvanger 1 en 2). Echter, deze verstoring lijkt locatie specifiek omdat de situatie bij de sluis voor schillende zender andere resultaten gaf bij verschillende zender locaties (zender A en B voor ontvanger 1 en 2). Om spook of misdetecties te voorkomen zal plaatsing van een ontvanger bij een damwand vermeden moeten worden indien er andere locaties beschikbaar zijn.

\subsection{Aanbevelingen}

Er moet bij een studie naar uittrek van schieraal gebruikmakend van de VEMCO techniek rekening worden gehouden met de volgende aspecten:

- De binnenzijde van het sluizencomplex lijkt gevoelig voor verstoring als gevolg van weerkaatsing van het akoestische signaal via damwanden. Daarom kunnen deze locaties het beste vermeden worden als een basis voor een eventueel experiment. Plaatsing aan een fuikpaal of bij voorkeur aan een boei geeft een meer betrouwbare detectiekans per signaal.

- Voor het meten van de uittrek is met name de meting aan de buitenzijde van belang. Een dubbele bezetting aan de buitenzijde van het complex heeft daarom de voorkeur, omdat een dubbele bezetting de (geringe) kans op ongezien passeren van schieraal bij detectiestations kan uitsluiten. Een dubbele (en meer) bezetting is ook toegepast bij het spuisluiscomplex te Kornwerderzand (Griffioen et al. 2014). De hoge dichtheid aan ontvangers gaf enerzijds een onderscheidingsvermogen en anderzijds gaf het ook een hoge zekerheid op doortrek detectie van de vissen. Hier zijn geen vreemde trajecten van gezenderde vissen gevonden waarbij detectiestations werden 'overgeslagen' c.q. gemist.

- Een enkele bezetting aan de binnenzijde van het sluiscomplex geeft naast de gevolgde route ook informatie over eventueel zoekgedrag indien men verder landinwaarts in het kanaal ook ontvangers heeft staan. Om een eventuele vertraging of zoekgedrag inzichtelijk te krijgen, zijn detecties aan de binnenzijde ook noodzakelijk. De ontvangers kunnen zowel op het kanaal als nabij de sluizen worden geplaatst en het liefst op beide locaties. Een dergelijke opstelling is ook bij een eerdere VEMCO studie in Friesland gebruikt (Keeken et al. 2013). Voor de locaties langs het kanaal lijken nr. 11 en 12, net oost van de veerpont Velsen, geschikt omdat het kanaal hier smal is.

- Dubbele bezetting op het kanaal geeft grote zekerheid op detectie. Het signaal kan namelijk gedurende meerdere minuten worden verstoord door de passage van zeer grote schepen. Een dubbele opstelling voorkomt dan een misdetectie. Daar komt bij dat de volledige breedte van het kanaal binnen de detectierange valt van de gebruikte V9-zenders (vb. Figuur 4.4 zender D en ontvanger 14 en 13). De kans op misdetectie is verwaarloosbaar indien men rekening houdt met een relatief hoge frequentie aan signalen ( $\mathrm{vb}$. om de 30-40 sec).

- Een merk-terugvangst experiment in het Noordzeekanaal met schieraal toonde aan dat sommige schieralen tot wel 39 dagen in het systeem bleven 'hangen' en een enkel individu wel enkele maanden (Griffioen and Winter 2017). Het gebruik van de krachtigere zender v9 wordt geadviseerd boven een V7 zender. Gezien de dimensies van de sluizen wordt een sterker signaal geadviseerd met een groot bereik. Een grotere zender, bijvoorbeeld een V13, zal mogelijk fysieke belemmeringen op kunnen leveren bij kleinere schieralen en zal door wellicht teveel detectiestations tegelijkertijd worden waargenomen, waardoor de misdetectiekans afwezig is, maar het onderscheidend vermogen via welke route wordt uitgetrokken kan verminderen t.o.v. een zender met een minder groot bereik.

- Het gebruik van referentie tags (stationaire zenders die gedurende de studie op een locatie blijven hangen) geeft een weergave van de misdetectiekans in het gebied. Deze zullen zowel aan de binnenzijde als aan de buitenzijde geplaatst kunnen worden. 
- Het aantal signalen per tijdseenheid van de zenders moet hoog zijn (1 signaal per ca. 30-40 $\mathrm{sec}$ ). De kans op misdetectie met een V9 zender wordt hiermee op $<0.00 \%$ ingeschat, gezien het grote bereik van de zenders. De batterijduur moet bij voorkeur minimaal 5 tot 6 maanden aangehouden worden om eventueel laat vertrekkende alen te kunnen detecteren. 


\section{$6 \quad$ Kwaliteitsborging}

Wageningen Marine Research beschikt over een ISO 9001:2008 gecertificeerd kwaliteitsmanagementsysteem (certificaatnummer: 187378-2015-AQ-NLD-RvA). Dit certificaat is geldig tot 15 september 2018. De organisatie is gecertificeerd sinds 27 februari 2001. De certificering is uitgevoerd door DNV Certification B.V.

Het chemisch laboratorium te IJ muiden beschikt over een NEN-EN-ISO/IEC 17025:2005 accreditatie voor testlaboratoria met nummer L097. Deze accreditatie is geldig tot 1 april 2021 en is voor het eerst verleend op 27 maart 1997; deze accreditatie is verleend door de Raad voor Accreditatie. Het chemisch laboratorium heeft hierdoor aangetoond in staat te zijn op technisch bekwame wijze valide resultaten te leveren en te werken volgens de ISO17025 norm. De scope (L097) met de geaccrediteerde analysemethoden is te vinden op de website van de Raad voor Accreditatie (www.rva.nl).

Op grond van deze accreditatie is het kwaliteitskenmerk $\mathrm{Q}$ toegekend aan de resultaten van die componenten die op de scope staan vermeld, mits aan alle kwaliteitseisen is voldaan.. Het kwaliteitskenmerk $Q$ staat vermeld in de tabellen met de onderzoeksresultaten. Indien het kwaliteitskenmerk $\mathrm{Q}$ niet staat vermeld is de reden hiervan vermeld.

De kwaliteit van de analysemethoden wordt op verschillende manieren gewaarborgd. De juistheid van de analysemethoden wordt regelmatig getoetst door deelname aan ringonderzoeken waaronder die georganiseerd door QUASIMEME. Indien geen ringonderzoek voorhanden is, wordt een tweede lijnscontrole uitgevoerd. Tevens wordt bij iedere meetserie een eerstelijnscontrole uitgevoerd.

Naast de lijnscontroles wordende volgende algemene kwaliteitscontroles uitgevoerd:

- Blanco onderzoek.

- Terugvinding (recovery).

- Interne standaard voor borging opwerkmethode.

- Injectie standard.

- Gevoeligheid.

Bovenstaande controles staan beschreven in Wageningen Marine Research werkvoorschrift ISW 2.10.2.105.

Indien gewenst kunnen gegevens met betrekking tot de prestatiekenmerken van de analysemethoden bij het chemisch laboratorium worden opgevraagd.

Indien sprake is van onbeheerste kwaliteit worden passende maatregelen genomen. 


\section{Literatuur}

Ammann, A. J., P. Sandstrom, E. Chapman, C. Michel, A. P. Klimley, S. Lindley, and R. B. MacFarlane. 2007. The performance of VEMCO V7, V9 and V16 transmitters and VR2 receivers under varying environmental conditions.in http://californiafishtracking.ucdavis.edu/CalFed_RangeTesting_2007.pdf, editor.

Griffioen, A. B., and H. V. Winter. 2017. Schieraal uittrek Noordzeekanaal 2016 - een merk-terugvangst experiment met fuikvangsten. Wageningen University \& Research Rapport C050/17.

Griffioen, A. B., H. V. Winter, O. A. v. Keeken, C. Chen, E. v. Os-Koomen, S. Schoenlau, and T. Zawadowski. 2014. Verspreidingsdynamiek, gedrag en voorkomen van diadrome vis bij Kornwerderzand t.b.v. de VismigratieRivier. I MARES, IJ muiden.

Keeken, O. A. v., M. v. Hoppe, I. J. d. Boois, M. d. Graaf, A. B. Griffioen, M. Lohman, E. v. Os-Koomen, H. J. Westerink, J. A. M. Wiegerinck, and H. M. J. v. Overzee. 2016. Toestand vis en visserij in de zoete Rijkswateren 2015 Deel III: Data. Wageningen Marine Research, IJ muiden.

Keeken, O. A. V., H. V. Winter, A. B. Griffioen, and M. d. Graaf. 2013. Silver eel behaviour in the vicinity of pumping stations: a telemetry study in Friesland. IMARES, IJ muiden.

Melnychuk, M. C. 2012. Detection efficiency in telemetry studies: definitions and evaluation methods. Pages 339-357 Detection efficiency in telemetry studies.

Thillart van den, G., V. van Ginneken, F. Korner, R. Heijmans, R. Van der Linden, and A. Gluvers. 2004. Endurance swimming of European eel. J ournal of Fish Biology 65:312-318.

Verbiest, H., A. Breukelaar, M. Ovidio, J.-C. Philippart, and C. Belpaire. 2012. Escapement success and patterns of downstream migration of female silver eel Anguilla anguilla in the River Meuse. Ecology of Freshwater Fish 21:395-403. 


\section{Verantwoording}

Rapportnummer:

Projectnummer:
$\mathrm{C} 060 / 17$

4316100115

Dit rapport is met grote zorgvuldigheid tot stand gekomen. De wetenschappelijke kwaliteit is intern getoetst door een collega-onderzoeker en het verantwoordelijk lid van het managementteam van Wageningen Marine Research

Akkoord:

Handtekening:

Datum:

Akkoord:

Handtekening:

Datum:
Harriet van Overzee

\section{Onderzoeker}

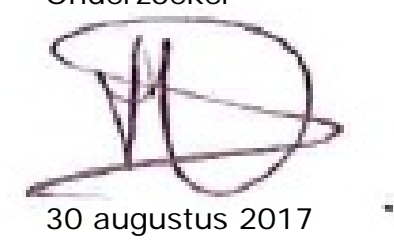

Drs. J. Asjes

Manager Integratie
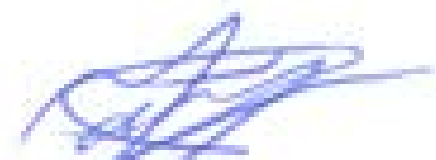

30 augustus 2017 


\section{Bijlage 1}

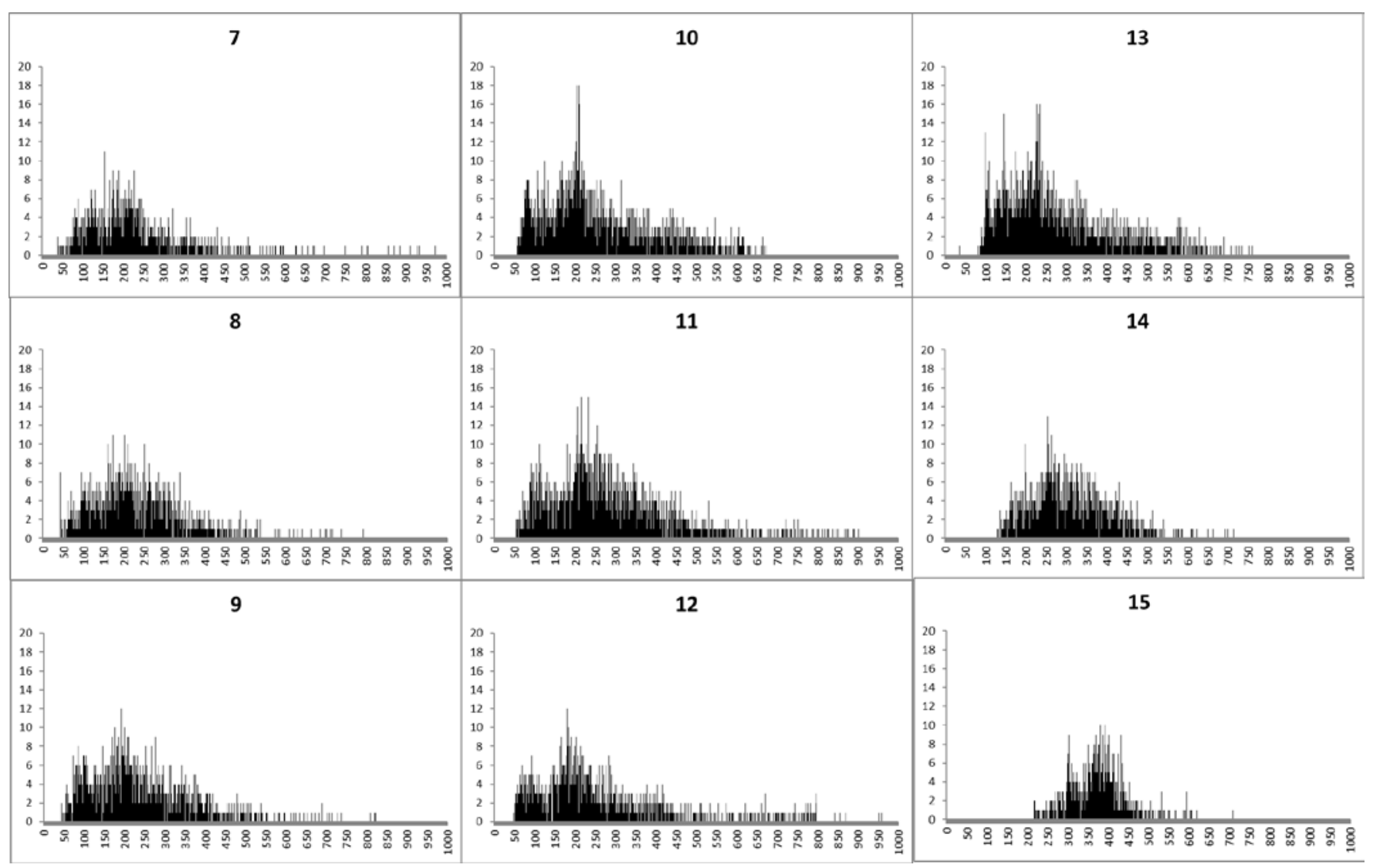

Figuur 6.1 Afstand van een zender ten opzichte van een ontvanger in meter (X-as 0-1000 meter) en het aantal detecties per afstand (Y-as) per locatie ten tijde van de kort lopende proef ( 2 dagen) waarbij gevaren is. NB. er is geen gelijke verdeling van kans op detectie per afstand. De figuur geeft een indruk van de reikwijdte van het akoestisch signaal van de ontvangers volgens deze opstelling. In de bijlage staat de detecties per ontvanger. 
Wageningen Marine Research T: +31 (0)317480900

E: marine-research@wur.nl www.wur.nl/marine-research

Visitors address

- Ankerpark 271781 AG Den Helder

- Korringaweg 7, 4401 NT Yerseke

- Haringkade 1, 1976 CP IJ muiden
Wageningen Marine Research is the Netherlands research institute established to provide the scientific support that is essential for developing policies and innovation in respect of the marine environment, fishery activities, aquaculture and the maritime sector.

Wageningen University \& Research is specialised in the domain of healthy food and living environment.

\section{The Wageningen Marine Research vision:}

'To explore the potential of marine nature to improve the quality of life.'

\section{The Wageningen Marine Research mission}

- To conduct research with the aim of acquiring knowledge and offering advice on the sustainable management and use of marine and coastal areas.

- Wageningen Marine Research is an independent, leading scientific research institute.

Wageningen Marine Research is part of the international knowledge organisation Wageningen UR (University \& Research centre). Within Wageningen UR, nine specialised research institutes of Stichting Wageningen Research (a Foundation) have joined forces with Wageningen University to help answer the most important questions in the domain of healthy food and living environment. 